\title{
Greywater as a Method of Water Conservation in Arroyo Grande
}

\author{
A Professional Project \\ By \\ DANIELLE CASTLE \\ June 10, 2010
}

\author{
In Partial Fulfillment \\ of the Requirements for the Degree \\ Master of City and Regional Planning
}

California Polytechnic State University, San Luis Obispo 
(C) 2010

Danielle Castle

ALL RIGHTS RESERVED 


\section{Abstract}

The purpose of this professional project is to address the practical implications of decentralized greywater usage in the City of Arroyo Grande. This professional project consists of two products: a brief greywater guide for the City and a background report. The greywater guide is intended for city planners to use for general information about greywater systems. The guide addresses Arroyo Grande's potable water shortage; what greywater is; advantages and concerns about greywater use; plants that are tolerant and intolerant of greywater irrigation; appropriate detergents to use with a greywater system; and a summary of California greywater law. The background report discusses the City of Arroyo Grande's potable water conditions and how water supply will be affected by growth projections for 2030. It is estimated that by the year 2030, Arroyo Grande's water demand will outgrow its water supply by 283 acre feet. Future water shortages are a concern at a local level and also on a global level. Three case studies examine how water scarcity has prompted the successful use of greywater. These studies examine the Hashemite Kingdom of Jordan; the Casa del Agua project in Arizona; and a local study in Santa Barbara, California. The report concludes with California greywater law, and how the recent change in August, 2009 has greatly increased the legal accessibility of greywater reuse as an obtainable method of water conservation. In combination with education and outreach among city officials and residents, greywater has potential to play a main role in water conservation in Arroyo Grande. 


\section{Committee Membership}

Title: Greywater as a Method of Water Conservation in Arroyo Grande

Author: Danielle Castle

Date Submitted: June 10th, 2010

\section{Dr. Adrienne Greve}

Committee Chairperson

Department of City and Regional Planning

$\underline{\text { Dr. Umut Toker }}$

Committee Member

Department of City and Regional Planning

\section{Kelly Heffernon}

Committee Member

Associate Planner, City of Arroyo Grande 


\section{Acknowledgements}

I would like to take this opportunity to express my genuine gratitude to my committee members, friends and family whose support and guidance made this project possible. I thank my chair, Dr. Adrienne Greve for allowing me the opportunity to work with her, for always holding confidence in me, and providing motivation so I could graduate on time. I thank Kelly Heffernon for taking the time to sit on my committee and provide a much-needed professional opinion on my work. I thank Umut Toker who always found the time in his insane schedule to help me when I needed it. I thank Shane Taylor for providing his expertise on Arroyo Grande's water condition, Alison Jordan for taking time to talk with me about greywater in Santa Barbara, and Martin Karpiscak for helping inform me on the details about the Casa del Agua project. I appreciate Claire Betar and Becky Powell for proofreading my final report and Peter Steynberg for allowing me to use his café as if it were my private office. I also want to thank my 18 housemates for making sure I don't take life too seriously. Special thanks to my wonderful parents whose love and support continuously shine throughout my crazy endeavors. 


\section{Contents}

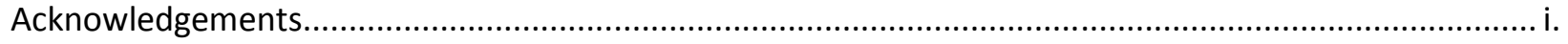

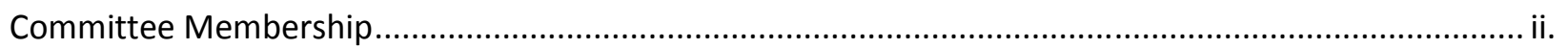

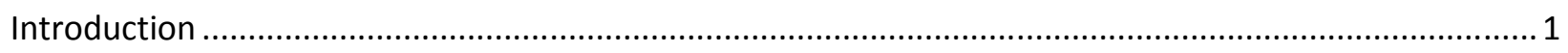

Why cities need to rethink Greywater .......................................................................................... 1

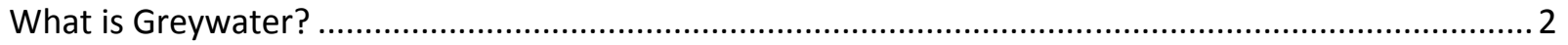

What constitutes a greywater treatment system? .......................................................................... 2

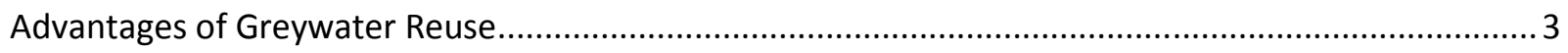

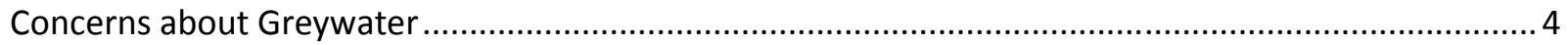

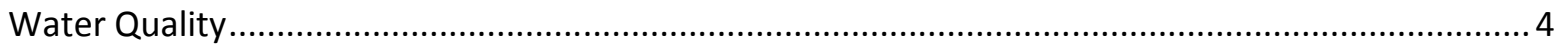

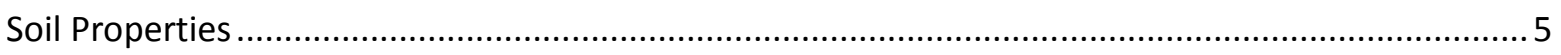

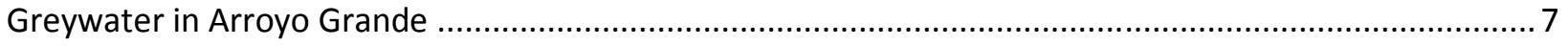

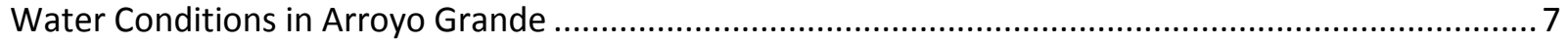

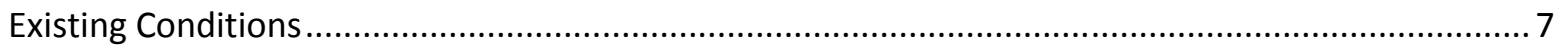

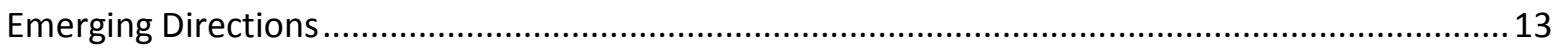

Water conservation projections for Arroyo Grande ......................................................................... 13

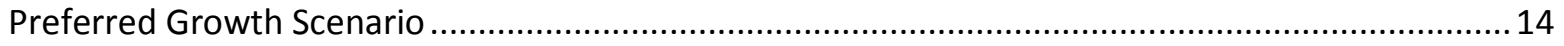

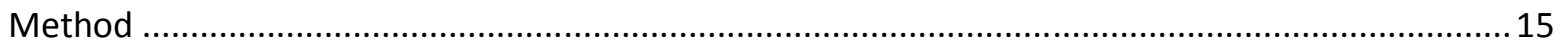

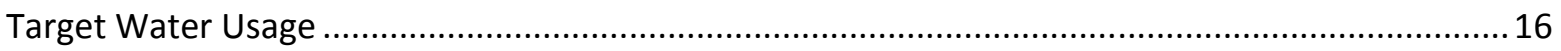

Potential Greywater Savings in Arroyo Grande ............................................................................. 17

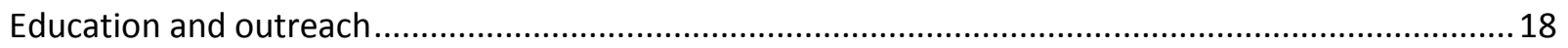

Greywater Case Studies: Jordan, Arizona, \& Santa Barbara ................................................................ 19

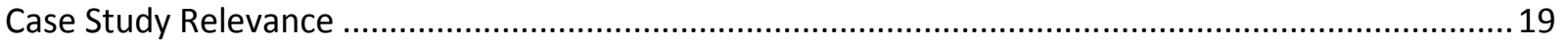

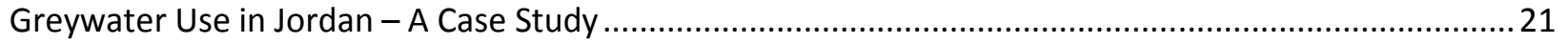

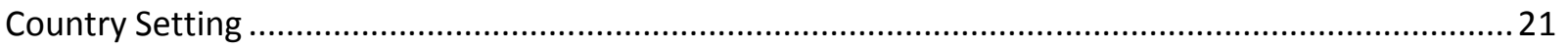

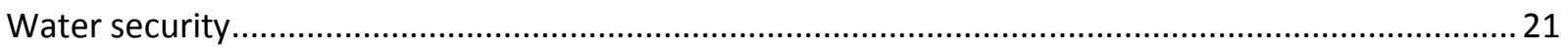

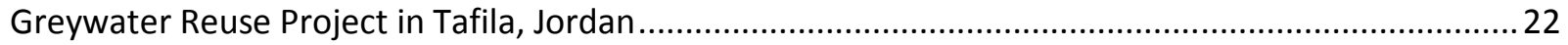

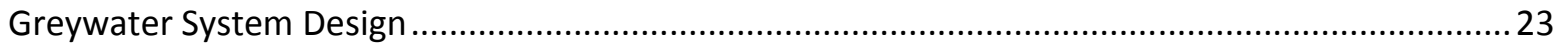

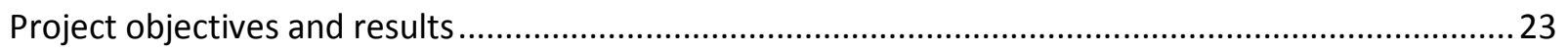

Increase greywater recovery and make it more convenient and safe to handle .............................24

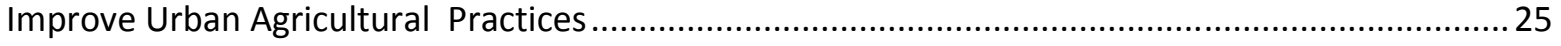


Promote changes in policies to encourage greater greywater reuse in Jordan .............................26

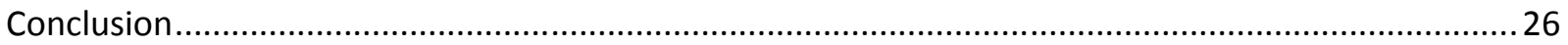

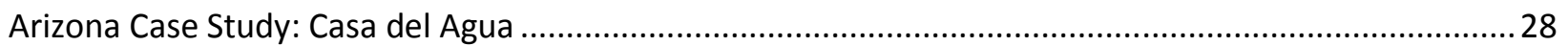

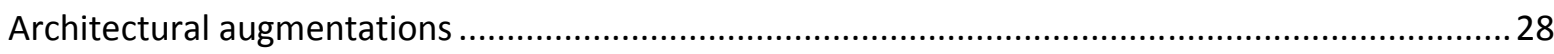

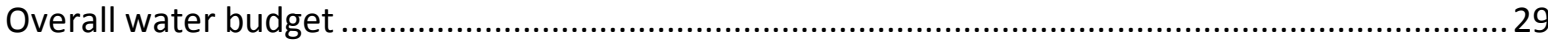

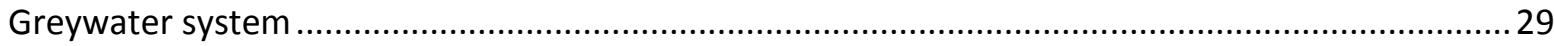

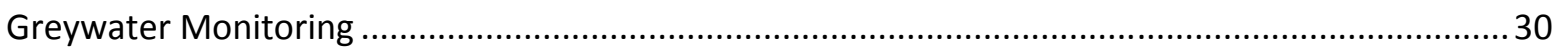

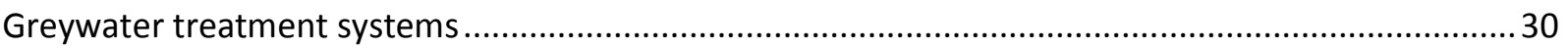

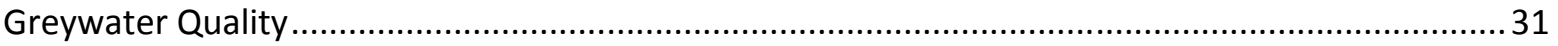

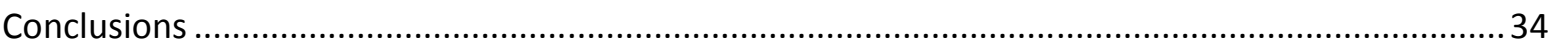

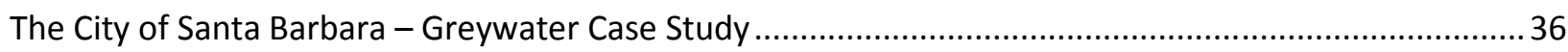

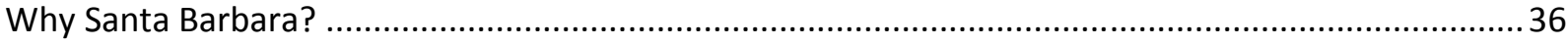

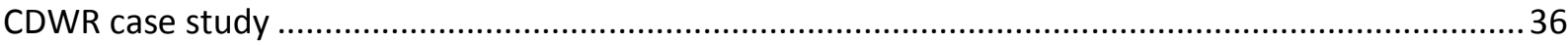

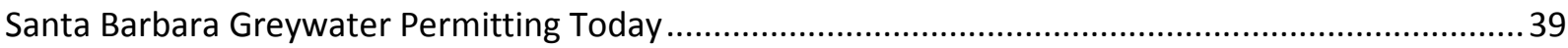

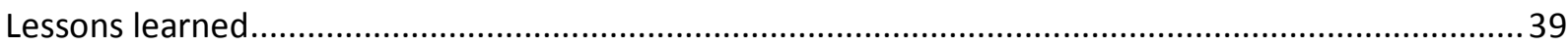

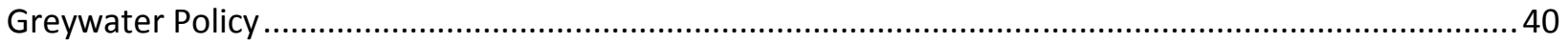

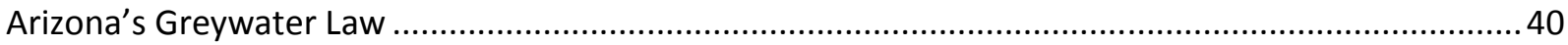

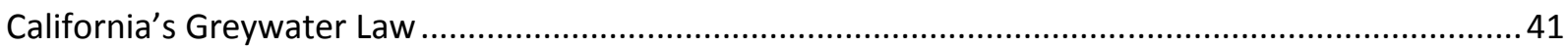

Arroyo Grande - Goals, Objectives and Policies.............................................................................. 43

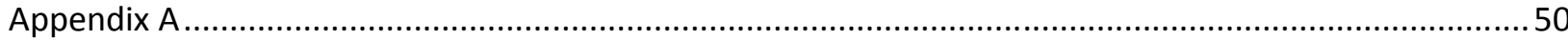

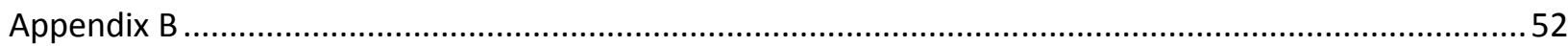

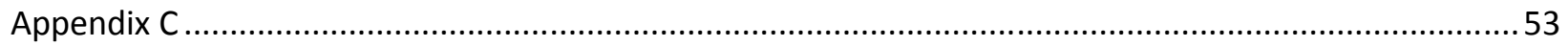




\section{Introduction}

\section{Why cities need to rethink Greywater}

The expansion of urbanization in water-scarce regions of the world is a phenomenon that has been occurring since industrialized technology, and is increasing the demand on potable water that cannot be sustained with current uses and attitudes toward this natural resource (Morrison, 2009; Gleick, 2003). In 2008, the world crossed an unseen line, where for the first time in history, more than half of the human population (3.3 billion people) was living in urban areas. It is expected that by 2030, this number will be reaching close to five billion (Schlein, 2007). Coupled with issues like global climate change and seawater intrusion, water managers are challenged to locate water sources that can support domestic, commercial, industrial and agricultural needs for an ever increasing customer base (Morrison, 2009; Cooley, 2009; Heberger, 2009). Making considerations beyond the urban realm, such as reserving base flows to support watershed health and entire ecosystems, also must be considered. Thus, greywater reuse is a single method of many water conservation tactics that urban centers should consider to reduce potable water waste, thinking beyond anthropocentric model and planning for water on an ecological scale. The importance of water reuse was acknowledged by UNESCO since the 1950 's, where "no higher quality water ... should be used for a purpose that can tolerate a lower grade" (Hespanhol, 2003), yet in 2010 it is still culturally accepted in the United States to flush fresh water down the toilet or use our urban potable water resources on landscaping. It is the task of planners and government agencies to educate themselves and the public to facilitate the adoption of greywater usage.

Dr. Gary H. Wolff, a senior economist with the Pacific Institute, states that his three years of research has shown that "myths and misunderstandings - not economics - are the biggest barriers to improving our water use efficiency" (Gleick, 2003). City planners, officials, and water managers have a responsibility to quash those myths and misunderstandings to promote changes that shift thought away from the exploitation of our dwindling resources to using, conserving and reusing what water is currently available. This can be achieved through education and from a "carrot" approach that offers incentives for residents to partake in greywater conservation practices. The future of humanity and biota depend upon the decisions that are made today, as potable water supply is a single factor that can make or break the success of a civilization.

The objective of this professional project is to provide city planners in Arroyo Grande with a concise guide about greywater supported by a detailed report. This includes the benefits and concerns about greywater; three case studies that provide examples of how greywater is used on a global, national and local level; the current and future water supply conditions of Arroyo Grande; and greywater policy with recommendations. This is not an instructional guide about 
how to build a greywater system, which can be found at SLO Greenbuild and the San Luis Obispo Greywater Guide.

\section{What is Greywater?}

Greywater is defined as "untreated wastewater that has not been contaminated by any toilet water, has not been affected by unhealthy bodily wastes, and does not present a threat from contamination by unhealthful processing, manufacturing, or operating wastes" (CPC, Chapter 16A Part I, 2007). In short, greywater is any wastewater that does not come from the kitchen or toilet. Greywater can be categorized as light or heavy. Light greywater is wastewater from the shower, bath, bathroom washbasin, and washing machine. Heavy greywater is wastewater from the kitchen sink and dishwater. The CPC requires heavy greywater to be treated as blackwater.

Any wastewater from the toilet is termed blackwater, and is acutely different than greywater by the means of nitrogen content, pathogen content and the rate of decomposition. Nitrogen is one of the more serious pollutants that threaten potable water supply, and the majority of this chemical leaving the home is derived from blackwater. Public health and safety's main concern is that human fecal matter possesses the most significant threat to spreading human pathogens. Keeping greywater separate from blackwater reduces the risk of human-borne pathogens in the wastewater stream. Greywater materials break down much quicker than blackwater wastes, meaning the greywater reaches a stable state in a shorter period of time, lowering the risk of pollution.

\section{What constitutes a greywater treatment system?}

There are multiple variations of greywater system design, but most treatment systems consist of five major components:

1. Collection of Greywater

2. Surge capacity

3. Filtration

4. Distribution

5. Utilization

The first step in a greywater treatment system is the collection of the wastewater. This can be achieved by individually plumbing laundry, shower or sinks to direct wastewater from these sources to a tank. Greywater collection can also be achieved by installing dual plumbing, which is especially recommended for a newly constructed house. The surge capacity tank is the first place the directed greywater may be stored or directed into a branched irrigation system. The surge tank can be gravity fed or pumped, and must be able to handle peak flows or it will cause pipes to back up. Filtration methods should minimize cleaning frequency and it is recommended systems to use automated sand filtration with backwash capabilities. Distribution of greywater can be achieved in many ways, such as a branched drip systems, miniature leach fields, vegetated leach field, mulched watering moat, sand filtered drip systems, and reed beds, to name a few. 
These distribution methods will vary based on site conditions and irrigation utilization (SLO Green Build, 2009).

\section{Advantages of Greywater Reuse}

There are many benefits to greywater reuse, including water conservation, reducing pressure on centralized water treatment plants, reduced carbon emissions, and improving watershed health. It is estimated that up to a third of California's urban water use (more than 2.3 million acre-feet) can be saved by using existing technology (Cain, 2003).

Greywater reuse benefits entire watersheds by transforming urban yards into miniature groundwater recharge basins instead of directing all wastewater into treatment plants. Groundwater supplies $83 \%$ of the annual agricultural and urban uses in the Central Coast Hydrologic Region, which includes San Luis Obispo, Santa Barbara, Monterey, San Benito and Santa Cruz counties (Davis, 2003). Groundwater is a part of the hydrologic cycle, which is the transfer of water (vapor, ice, or liquid) on the earth's surface, atmosphere, or below ground (figure 1). Although groundwater is politically managed as a separate entity from surface water, they are hydrologically linked. Groundwater can discharge water into surface streams, or surface streams can recharge groundwater. Aquifers near the coast are hydraulically connected to the ocean, resulting in seawater intrusion where overdrafting has occurred. Thus, greywater can contribute to the process of groundwater recharge.

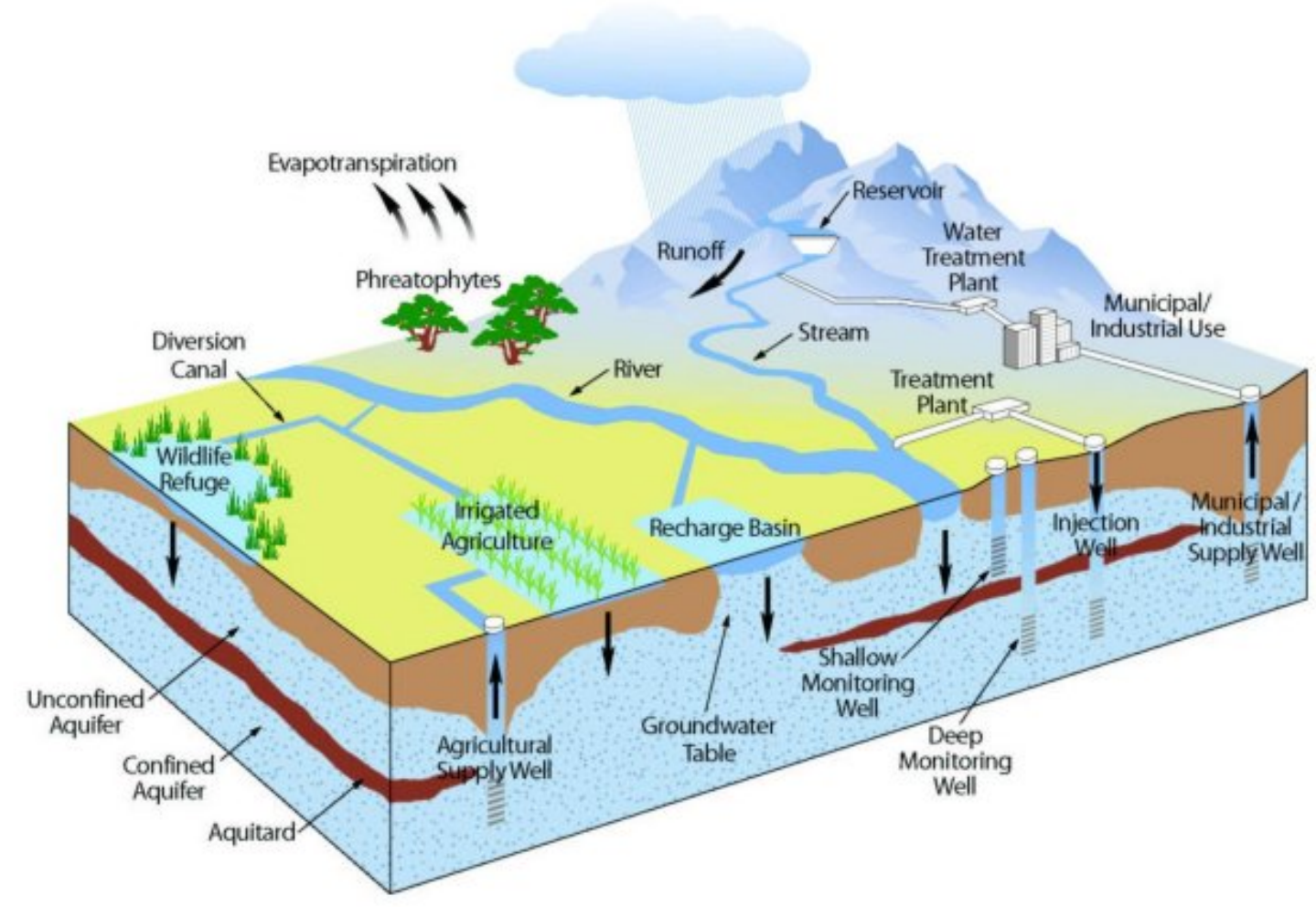

Figure 1 Hydrologic cycle http://www.water.ca.gov/groundwater/groundwater_basics/hydrologic_cycle.cfm 
Political attention has recently been directed at global climate change, and has been attributed to the release of greenhouse gasses (GHG) into the atmosphere. Countries are working on cap and trade programs for GHGs and climate action plans are concentrating on how to monitor, regulate, and reduce these emissions. Government bodies are quickly being held responsible for GHG emissions from their cities and countries. Moving municipal water to and from homes on the grid is energetically expensive and consequently, stands as a major supplier of greenhouse gas emissions. Water translocation in California generally occurs from the north where $70 \%$ the water is located, to the south where $75 \%$ of the State's urban and agricultural water demand is (Bulletin 118, 2003). The California Energy Commission (CEC) approximates that $19 \%$ of all electricity used in the state goes toward moving water. In addition, $30 \%$ of all natural gas consumption and more than 80 million gallons of fuel go toward water movement around the state (CEC, 2005). Decentralized greywater systems would immediately reduce energy costs, as greywater does not have to move any great distance, and many well-designed systems on appropriate sites are gravity-fed. Coupled with rainwater harvesting, the energy savings can be substantial.

Greywater eases strain on wastewater treatment facilities by reducing the volume of water that would need to be processed. Wastewater treatment facilities are continuously collecting and treating millions of gallons of wastewater every day every year. The South San Luis Obispo County Sanitation District is responsible for over eight miles of trunk main and sewer pipes from the Cities of Arroyo Grande, Grover Beach, and the Oceano Community Services District. The combined average annual raw wastewater flow from these agencies is about 2.9 million gallons per day, where Arroyo Grande alone contributes about 1.26 million gallons of raw wastewater per day (South San Luis Obispo County Sanitation District, 2008). The California Wastewater Training and Research Center (2003) claims that some of the most common cause of wastewater treatment system failure is Hydraulic overload. This occurs when more water is entering the system than system components were designed to process. Greywater systems provide a partial solution to hydraulic overload because it reduces the volume of wastewater that is being sent to a treatment facility. In addition to reducing environmental hazards of system overload, greywater also reduces processing costs for users by $31 \%$ when compared to municipal wastewater processing (Ferguson, 2009).

\section{Concerns about Greywater}

\section{Water Quality}

The foremost concern about greywater usage is its effect on public health and safety. Out of eight million greywater systems in the United States, there have been zero documented cases of greywater transmitted illnesses (Ludwig, 2009; personal communication Alison Jordan). Despite this, policy makers have historically been reluctant to endorse the widespread adoption of greywater due to social stigmas attached to wastewater reuse. These perceptions have thwarted many good intentions and ideas for managing greywater use, indicating that there is a need for public education about greywater reuse.

A study in Sweden looked at microbial risk models for reused greywater. The researchers recognized that the source of fecal coliforms in a wastewater stream is mainly from laundry, diapers, childcare, and showering. In a community north of Stockholm, Sweden, this fecal input was measured to be 0.04 grams per person per day (Ottoson, 2002), indicating the risk of 
transmitted illness from fecal coliforms is very low. The study also looks into Salmonella and Campylobacter bacteria that can be introduced into the wastewater system from contaminated kitchen waste. The concern is that these pathogens can survive and reproduce in the plumbing. The results show that under normal conditions, these bacteria died off rapidly. Competition between normally occurring and pathogenic organisms was imperative to keep bacteria at safe levels.

Although it is highly unlikely that humans will get sick from greywater reuse, untreated greywater is a potential environmental hazard for watersheds. Laundry water is a source of phosphorous and kitchen waste is a source of nitrogen. Phosphorous and nitrogen are two major components to plant fertilizers, and if these wastewaters are directed toward irrigation, then these nutrients can help plant growth (Gross, 2005; Travis, 2010). However, if these nutrients are disposed of in surface waters, then they can pose a serious environmental hazard by inducing algal blooms and eutrophication (Redwood, 2010).

\section{Soil Properties}

\section{Salt Build Up}

Greywater systems may cause salt to build up in the soil, particularly in warmer areas where higher rates of evaporation occur. Water hardness is a measure of calcium and magnesium dissolved in water. In San Luis Obispo, water hardness is at moderate level at 200-370 mg/l, where groundwater hardness levels tend to be higher than surface water levels. It is assumed that similar levels of water hardness are found in nearby Arroyo Grande. As a result, water softeners are commonly used, and the effects of salt build up in soils can be a concern. According to the SLO Greywater Guide, water softeners can be leached out by flushing the system with fresh water. Every 1000 square feet of property can yield 600 gallons of water in a single inch rainstorm (SLO Green Build, 2009). By strategically directing stormwater runoff into the landscape, greywater is flushed naturally and salt build up does not become an issue.

\section{Effluent on soil}

Environmental effects of small scale greywater effluent on soil health are a concern. Greywater usage in many countries consists of irrigating plants with untreated greywater, which may have potential detrimental effects on soil properties. However, treated greywater can be used to effectively irrigate plants without having detrimental effects on the soil or plant growth (Travis, 2010).

Environmental effects of greywater effluent on soil and plants were tested in a 2008 study by treating greywater with various treatment principals (biological, physical, electrolysis) and used each type to irrigate lettuce plants, which are considerably sensitive to water quality. The study results found that untreated greywater released on soil can cause environmental and plant damage, however treated greywater can meet current wastewater standards for unlimited irrigation with the exception of fecal coliform removal. These bacteria can be removed by the 
addition of a small disinfection unit. It has also been documented that fecal coliforms do not survive in soil (Gross, 2005).

\section{Food Crop Irrigation}

Greywater reuse on home gardens has become a common practice as water resources decline (Finley, 2009; Godfrey, 2009). However, there are concerns about sanitation, where the risk factors are unknown. In Finley's 2008 study, it was found that there was no significant difference in fecal coliform levels between tap water and Greywater treatment groups. The highest fecal coliform counts were found on carrots, which makes sense because the edible root is in direct contact with the soil and irrigation water. Surprisingly, the control blocks showed a higher but not statistically significant level of fecal coliform counts than Greywater-irrigated groups. The risks associated with irrigating edible crops with Greywater are difficult to assess due to a lack of published microbial standards for fresh produce. According to the International commission on Microbiological Specifications for Food, a recommended limit for E. coli was a limit of 100 $\mathrm{CFU} / \mathrm{g}$ on fruits and vegetables for a sample size of at least five with no two samples exceeding that limit. The results from this study did not surpass this level, nor did any sample alone exceed it. The study results suggest that the use of household Greywater for irrigation does not directly correlate to higher levels of bacterial contamination. As the same indicator bacteria present in Greywater were detected on crop surfaces, those numbers were not significantly different than those found the tap water control irrigation groups. 


\section{Greywater in Arroyo Grande}

To determine the effectiveness of greywater usage in Arroyo Grande, it is necessary to explore the existing water conditions and projections for the City. This section will discuss the water supply, demand, and threats to Arroyo Grande's water supply. Then, estimated growth projections and future water demand were calculated using a state approved projections calculator. Lastly, estimated water conservation savings are calculated, starting with existing techniques, and then calculating greywater savings. Greywater savings are based on different participation rates for single family homes.

\section{Water Conditions in Arroyo Grande}

Water conservation is an optional element of the general plan if treated as separate from the conservation element. There are few other natural resources that can impede the operation of a civilization like the shortage of potable water. While information on water is usually included in a city's general plan, it is not usually located in a single section; the information on policy, inventories, and supply and demand analyses is oftentimes scattered throughout the document. A goal for Arroyo Grande's general plan update is to provide a specific water conservation subelement for easily accessible information. This background report section reviews the conditions of existing water supply, water demand, threats to water supply, existing conservation efforts, alternative water sources, and makes suggestions for possible policies based on community aspirations.

\section{Existing Conditions}

\section{Water Supply}

The sources of Arroyo Grande's water supply are the Lopez reservoir and groundwater (see table 1). The Lopez Reservoir supplies water for Arroyo Grande, Grover Beach, Oceano Community Services District, Avila Beach CSD, Port San Luis, CSA-12, Avila Valley MWC, and Pismo Beach, and is operated by the San Luis Obispo County Flood Control and Water Conservation District (SLOFCWCD). Lopez Reservoir has a capacity of approximately 50,000 acre-feet (Urban Water Management Plan, 2005). Between all the water contractors, the total water entitlement is 4,530 acre feet per year (AFY). Downstream releases and Safe Yield from Lopez Reservoir are 4,200 AFY and 8,730 AFY, respectively (Todd Engineers, 2009). Downstream release is the amount of water discharged into Arroyo Grande Creek. The purpose of this is to maintain a continual water supply for habitat usage, agriculture and groundwater recharge. The safe yield reflects the amount of sustainable water supply during a drought. As of 2009, Arroyo Grande is not contracted to receive water from the State Water Project (SWP). 
Of the available water supply, groundwater comes from the Arroyo Grande Groundwater Basin and the Pismo Formation Groundwater Basin. Four urban agencies extract water from the Arroyo Grande Groundwater Basin. These are the City of Arroyo Grande, the City of Grover Beach, the City of Pismo Beach, and the Oceano CSD. Each of these municipalities entered a Groundwater Management Agreement in 1982 (also referred to as the Gentlemen's Agreement) that specifies division of safe yield of the basin, which is 9,500 AFY. Other uses for the basin include agriculture (5,300 AFY) and subsurface flow to the Pacific Ocean (200 AFY). This is the main source of groundwater for the region. The Pismo Formation Groundwater Basin contributes a smaller supply, and as of 2005 has the capability of supplying 70 AFY (UWMP, 2005).

As of 2009, Arroyo Grande has an agreement to purchase 100 AFY of Oceano CSD entitlement that comes from either groundwater or from the Lopez Reservoir. Well 9 in table 1 include groundwater from beyond the Northern Counties Management Area. Well 10 is expected to be in operation by fall of 2010, with an anticipated yield of 90 AFY.

\begin{tabular}{|l|l|l|l|l|l|}
\hline Table 1: Available Urban Water Supply in Arroyo Grande (AFY) & Total \\
\hline $\begin{array}{l}\text { Lopez } \\
\text { Entitlement }\end{array}$ & $\begin{array}{l}\text { Groundwater } \\
\text { Entitlement }\end{array}$ & $\begin{array}{l}\text { OCSD } \\
\text { Purchase } \\
\text { Transfer }\end{array}$ & $\begin{array}{l}\text { SWP } \\
\text { Allocation }\end{array}$ & Well 9 & 3,794 \\
\hline 2,290 & 1,314 & 100 & 0 & 90 & \\
\hline
\end{tabular}

Table source: Personal communication: Shane Taylor (Utilities Supervisor), Kelly Heffernon (Associate Planner) May 10, 2010

\section{Water Use and Demand}

Arroyo Grande's per capita water consumption in 2005 was 183 gallons per day (gpd) (AG Urban Water Management Plan, 2005). The largest portion of urban water usage goes toward Residential -Single Family (RSF) (table 2). Seventy-two percent of the city's water was consumed by RSF, which averaged 425 gallons per day. This customer category includes outdoor irrigation, where over half of this amount will be used on turf grass. 


\begin{tabular}{|l|r|r|r|r|r|}
\hline \multicolumn{7}{|l|}{ Table 2: Historical water usage by category in Arroyo Grande } \\
\hline & 1990 & 1995 & 2000 & 2005 & $\begin{array}{r}\% \\
2005\end{array}$ \\
\hline & 2104 & 1892 & 2436 & 2459 & $72 \%$ \\
\hline Residential Single Family & 263 & 237 & 305 & 307 & $9 \%$ \\
\hline Residential Multi-family & 351 & 315 & 406 & 410 & $12 \%$ \\
\hline & 29 & 26 & 34 & 34 & $1 \%$ \\
\hline Commerical/ institutional & 175 & 158 & 203 & 205 & $6 \%$ \\
\hline Governmental & 2922 & 2628 & 3384 & 3415 & $100 \%$ \\
\hline $\begin{array}{l}\text { Landscape irrigation/ Public } \\
\text { facility }\end{array}$ & & & & & \\
\hline Total & & & & & \\
\hline Source: Arroyo Grande Urban Water Management Plan 2005 & & \\
\hline
\end{tabular}

\section{Threats to Water Supply}

Shortage of potable water is a global issue and Arroyo Grande is no exception. State-wide drought and global climate change are issues that threaten coastal communities (Gleick, 2000; Herberger, 2009; Stenekes, 2006). Seawater intrusion has also become a potential threat to groundwater quality in Arroyo Grande (Hodgson, 2010, Hodgson 2009). These are issues that must be kept in mind when planning for future development.

\section{Potential Seawater Intrusion}

Many coastal supplies of groundwater (or aquifers) around the world are threatened by seawater intrusion (Goldman, 1991, Xue, 1995, Nowroozi, 1999). Seawater intrusion is the flow of seawater into freshwater aquifers induced by groundwater pumping (figure 2). When groundwater is pumped from aquifers, there is a hydraulic connection with the sea, so as fresh water is

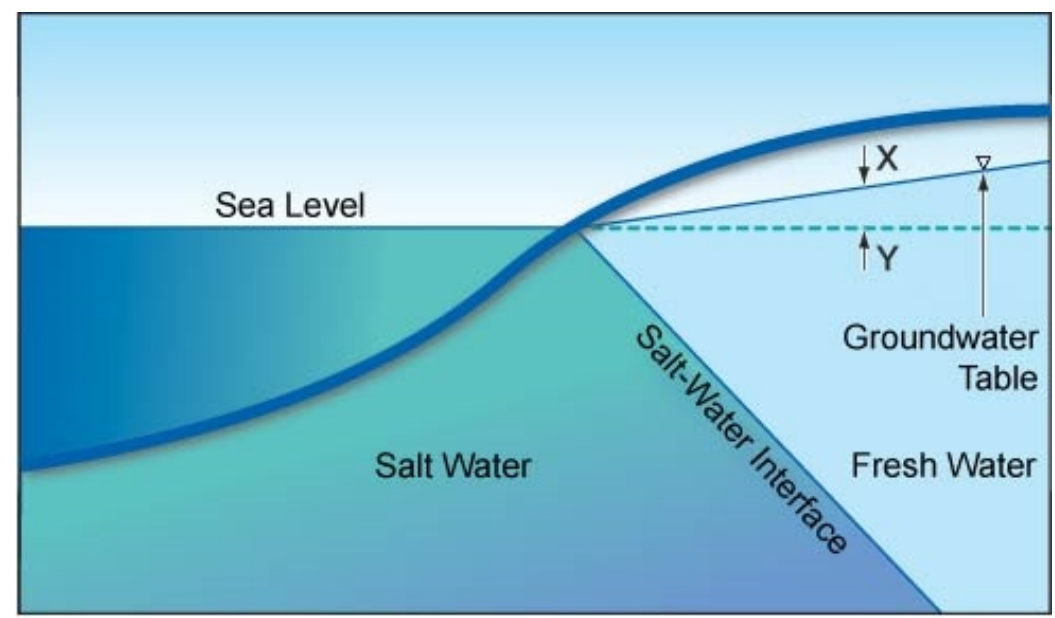

Figure 2 Diagram of seawater-groundwater interface (Source: Solonist http://www.solinst.com/Res/papers/101C4Salt.html) 
pulled out of the ground, seawater is pulled into the aquifer. This mixing of fresh water with sea water is a threat to potable water supply because when there is an influx of saltwater, the groundwater is contaminated and then must be treated. Groundwater treatment is a costly process. In order to control seawater intrusion, a balance must be maintained between water being pumped from the aquifer and the amount of freshwater recharging the aquifer. This requires rigorous monitoring of the freshwater-seawater interface.

The northern cities, Arroyo Grande, Grover Beach, Oceano and Pismo Beach, have developed a water quality sampling program that surveys sentry wells to ensure accurate groundwater level measurements. There are also collaborative strategies being undertaken to reduce coastal groundwater pumping and increase the use of other available water supplies (Todd Engineers, 2009).

The region around Arroyo Grande is underlain by an aquifer where the freshwater-saltwater interface is unknown as of 2009. There is historical evidence of a net outflow of freshwater from the groundwater basin to the ocean. This was determined by the presence of onshore groundwater elevations above sea level that indicate a groundwater flow toward the ocean.

Monitoring wells, or sentry wells, gauge groundwater elevations in Arroyo Grande in the spring and fall of each year. Seasonal patterns are reflected in groundwater levels, which are generally high in the spring and lower in the fall. In the fall of 2008, two sentry wells indicated that groundwater levels were below sea level, which may be a sign of seawater intrusion. On November 10, 2009, the City Council approved a 45-day moratorium on new development projects. An extension of four months and 15 days was approved on December 8 . Before the deadline hit on April $23^{\text {rd }}$, the Council approved the final three month extension on the moratorium to allow staff more time to assess future groundwater conditions (Hodgson, 2010).

\section{Conservation Efforts}

The Cash for Grass program is aimed to "encourage a permanent reduction in the amount of water used for landscaping" (City of AG, 2009). It is estimated that about $60 \%$ of the city's water supply is used on urban landscaping, especially lawns. The Cash for Grass Program provides landowners an incentive to convert their lawn into a drought-tolerant landscape. The program offers $\$ 0.50$ per square foot of grass removed, which will be distributed at a minimum of 250 square feet $(\$ 125)$ and a maximum of 5,000 square feet $(\$ 2,500)$.

The sustainable landscape seminar series offers free seminars that educate the public about water conservation and xeriscaping. Xeriscaping is the use of drought-tolerant plants in the landscape to reduce the amount of irrigation used. The seminars are offered every second Thursday of the month from 6:00pm to 8:00pm at the City Council Chambers, and are also televised on Channel 21. 
The smart irrigation controller and sensor program provides a free upgrade of old irrigation controllers to new ones with weather-based sensor technology. These controllers have sensors that gauge the watering needs of the plants and water accordingly, which reduces the amount of wasted water.

The water efficient washing machine rebate program incentivizes residents to trade out old inefficient washing machines to a newer water conserving model. The City is offering a $\$ 100$ to $\$ 150$ refund to residents who purchase new water efficient machines.

\section{Alternate Water Sources}

The City of Arroyo Grande is considering alternate water sources to reduce the strain upon existing surface and groundwater supplies. These include the extension of the Nacimiento pipeline and a desalination facility. There is a feasibility study on expanding the water capacity of Lopez Reservoir.

\section{Nacimiento Pipeline Extension}

In 1959, San Luis Obispo County secured entitlement to 17,500 AFY of water from Lake Nacimiento, a water body in Monterey County. In 2003, the county completed a final draft Environmental Impact Report (EIR) for developing a 45-mile pipeline that extends from Lake Nacimiento and ends at the water treatment facility in the City of San Luis Obispo. The cost of the project totaled at $\$ 176$ million, yielding the largest single project in the history of SLO County (Ogren, 2009). In October, 2007 the County broke ground to begin the pipeline installation. As of 2009, the installation is approximately 94\% complete (Hollenbeck, 2009). The planned pipeline will service Paso Robles, Templeton, Atascadero, and San Luis Obispo (table 3).

\begin{tabular}{|l|r|}
\hline Table 3: Participants and entitlements of Nacimiento Water \\
\hline Participant & Entitlement AFY \\
\hline Paso Robles & 4000 \\
\hline San Luis Obispo & 3380 \\
\hline Atascadero & 2000 \\
\hline Templeton CSD & 250 \\
\hline Total & 9630 \\
\hline Source: Urban Water Management Plan 2005 \\
\hline
\end{tabular}

As of 2009, there is a total of 9,630 AFY accounted for, which leaves 7,870 AFY of water with no immediate plans for its distribution. The City of Arroyo Grande prepared a draft feasibility study in January 2006 to assess how costly it would be to extend the Nacimiento pipeline from the San Luis Obispo water treatment plant to the Lopez water treatment plant to provide additional water by the South SLO County water agencies. The feasibility study assumes that the extension of the waterline would require a supplemental EIR, additional 18 miles of 
construction, installation of another booster pump, and possible upgrades to the existing Lopez treatment and distribution system. The estimated cost for this project would be somewhere between $\$ 3,000$ and $\$ 3,800$ per acre-foot of water for a supply of 750 AFY to Arroyo Grande.

\section{Desalination}

In January, 2006 a feasibility study was conducted to evaluate the possibility of obtaining 750 AFY for Arroyo Grande from seawater desalination. The total cost for a desalination plant would be $\$ 2,675$ per acre-foot of water. This value is based on a 20 year life cycle cost analysis, and includes a $20 \%$ contingency and all capital costs were multiplied by a factor of 1.4 to account for soft costs. The 2006 study was used to secure a Proposition 50 grant to further evaluate the possibility of installing a desalination facility. The Desalination Funding Study was completed in October 2008 and evaluated raw water supply options, treatment plant layout, brine disposal and outfall, product water delivery, environmental considerations, permitting and approvals, and water project costs (Todd Engineers, 2009).

The best location for a desalination facility would be at the existing South SLO County Sanitation District Wastewater Treatment Plant in Oceano which is located directly on the coastline, and as a result could service Arroyo Grande, Oceano, and Grover Beach. The coastal location also provides a direct source for water intake and a likely location for brine disposal as well as an ocean outfall for treated wastewater effluent. A desalination facility would likely involve a more complicated permitting process. However, it is the only suggested water source that is not affected by drought conditions. It has the benefit of being able to provide a constant supply of water regardless of water shortages throughout the region. The next steps include a written agreement among water agencies, initiation of the CEQA process, and design studies.

\section{Lopez Reservoir Expansion}

In 2008, SLO County sponsored a preliminary study of installing gates on the Lopez Dam spillway. This would raise the maximum storage capacity by three feet, which would yield 49,400 to 52,350 acre-feet. The estimated additional urban yield ranges from 671 to 916 AFY. The next steps would involve assessment of dam safety, evaluation of project benefits, identification of alternatives, engineering feasibility studies, environmental review, permitting, design, and construction (Todd Engineers, 2009).

\section{Standards and Policies}

As of 2009, Arroyo Grande is in a "Severely Restricted Water Supply Condition," meaning the city is consuming 95-99\% of the annual available water supply. The City has responded by placing mandatory water conservation measures via the Arroyo Grande Municipal Code (Chapter 13.05). These measures focus on citizen behavior regarding water usage, such as time restrictions on outdoor irrigation and water use of excessive gutter runoff. Violations of these water conservation measures are subject to penalty as follows: 


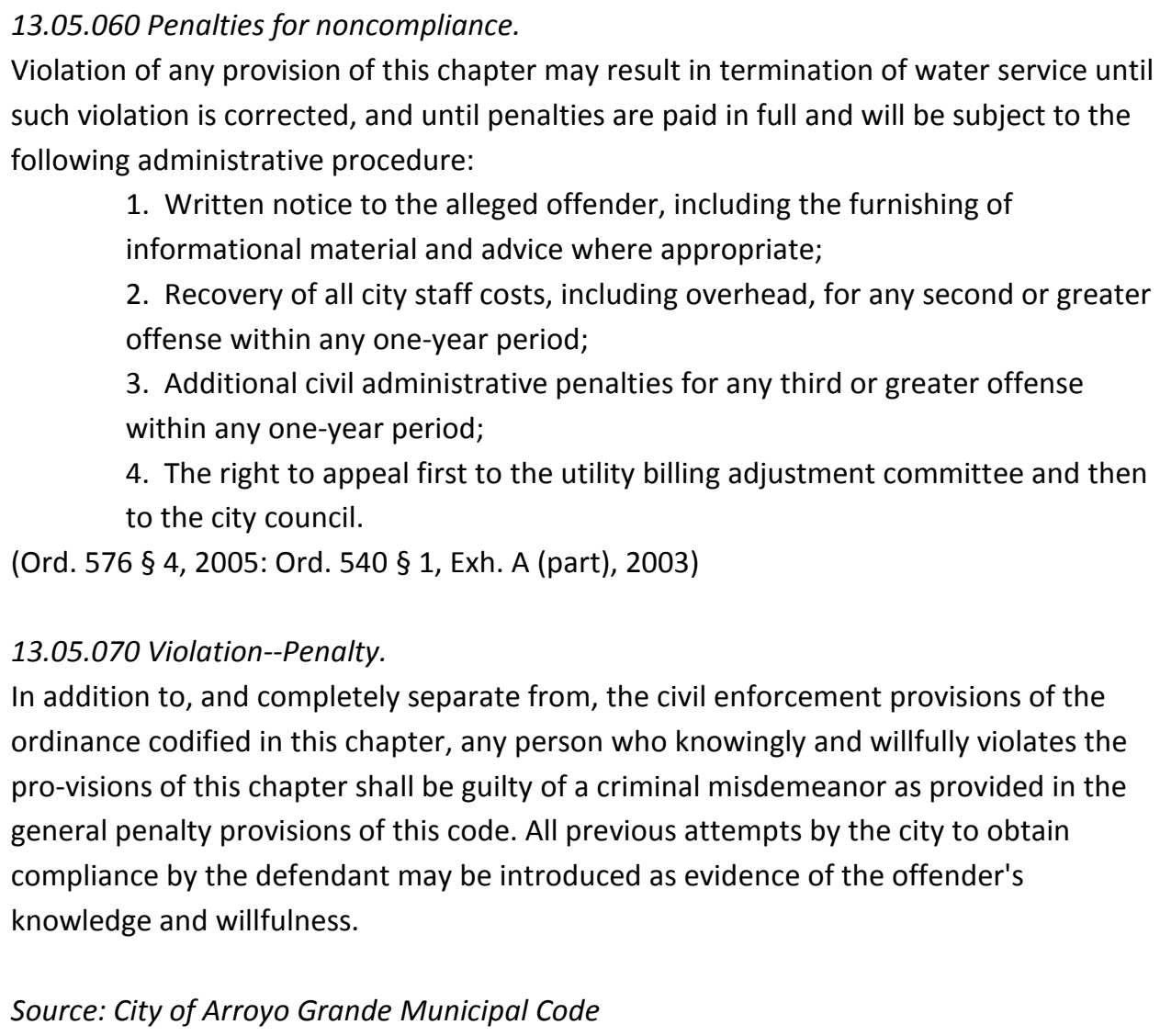

4. The right to appeal first to the utility billing adjustment committee and then to the city council.

(Ord. 576 §, 2005: Ord. $540 \S 1$, Exh. A (part), 2003)

\subsubsection{Violation--Penalty.}

In addition to, and completely separate from, the civil enforcement provisions of the ordinance codified in this chapter, any person who knowingly and willfully violates the pro-visions of this chapter shall be guilty of a criminal misdemeanor as provided in the general penalty provisions of this code. All previous attempts by the city to obtain compliance by the defendant may be introduced as evidence of the offender's knowledge and willfulness.

Source: City of Arroyo Grande Municipal Code

\section{Emerging Directions}

\section{Community Aspirations}

According to the Urban Water Management Plan (2005), the population of Arroyo Grande is expected to increase to 20,000 in the next twenty-five years. As the city is largely built out, future development is expected to be infill of homes on larger lots in the City's rural areas and an increase of residents on smaller lots and planned developments in the City's single family and mixed use districts. Based on public meetings, the community of Arroyo Grande is aware and has expressed concern about water conservation issues. Outreach and education about water supply and alternative conservation methods holds high potential in Arroyo Grande.

\section{Water conservation projections for Arroyo Grande}

Water availability for the City of Arroyo Grande is a critical issue that must be addressed when considering future development. The city has constructed a four-tiered scale to quantify the condition of water supply in the city (table 4). Based on this scale, the City Council has the ability to adopt resolutions that prohibit certain practices which result in lower water use. Detailed measures on each condition rating are listed in Appendix A as stated in Arroyo Grande's municipal code. 


\begin{tabular}{|l|l|}
\hline $\begin{array}{l}\text { Table 4: Range percentages of water supply } \\
\text { conditions in Arroyo Grande }\end{array}$ \\
\hline Water supply condition & $\begin{array}{l}\text { Max. Percentage } \\
\text { Use }\end{array}$ \\
\hline Normal & $>89.9 \%$ \\
\hline Moderate & $90-94.9 \%$ \\
\hline Severe & $95-98.9 \%$ \\
\hline Critical & $99-100 \%$ \\
\hline *Source: Arroyo Grande Municipal Code, \\
13.05.010 Water supply conditions. \\
\hline
\end{tabular}

The water supply condition in Arroyo Grande was calculated for 2005 and 2008 (table 2). In 2005, the total supply of water was 3,794 AFY, and the amount of water used was 3,415 AFY. This means $90 \%$ (or more than 3,382 AFY) of the water supply was used, which places Arroyo Grande in the Moderate water supply condition range. In 2008, 95\% of the water supply was used, which places that year in the severely restricted water supply conditions category. Based on these water supply conditions, Arroyo Grande has mandated that there be strict water conservation measures to be taken (Appendix B).

Table 5: Comparison of 2005 and 2008 data on water supply conditions

\begin{tabular}{|c|c|c|c|c|c|c|}
\hline Year & $\begin{array}{l}\text { Water } \\
\text { supply } \\
\text { Condition }\end{array}$ & $\begin{array}{l}\text { Max. Percentage } \\
\text { Use }\end{array}$ & $\begin{array}{l}2005 \text { Supply } \\
\text { (AFY) }\end{array}$ & $\begin{array}{l}\text { Received } \\
\text { (AFY) }\end{array}$ & $\begin{array}{l}\text { Baseline for } \\
\text { each } \\
\text { condition } \\
\text { (AFY) }\end{array}$ & $\begin{array}{l}\% \text { Water } \\
\text { used }\end{array}$ \\
\hline 2005 & Moderate & $90-94.9 \%$ & 3758 & 3415 & 3382 & $91 \%$ \\
\hline 2008 & Severe & $95-98.9 \%$ & 3696 & 3514 & 3511 & $95 \%$ \\
\hline
\end{tabular}

*Source: Supply and received numbers came from personal communication with Shane Taylor, the Public Works Supervisor of Arroyo Grande on January 20, 2010.

These data are critical for water supply and use projections. Three development scenarios were proposed to project the form of Arroyo Grande in 2030: 1. "Business as Usual"; 2. Conservation development; and 3. Comprehensive growth model. Each development scenario was presented at a public meeting to receive critique, and a preferred growth scenario was crafted based on these comments.

\section{PREFERRED GROWTH SCENARIO}

The preferred growth scenario for 2030 bases target growth models based on an estimated population projection of 17,370 people living in Arroyo Grande. The distribution of development is a hybrid between the "business as usual" and conservation growth scenarios, which propose a 
moderately denser development around the Grand Avenue corridor while leaving fringe areas of the city undeveloped. This scenario plans for an increase of mixed use development, where dwelling units may reside above workspaces. This indicates that there may be a decrease in household size and an increase in mixed use development. This shift in development type will have an effect on water usage.

\section{Method}

Water projections estimate how much water will be required to support future visions of Arroyo Grande. These projections are calculated by multiplying future land use type by their respective water duty factor. The water duty factor is the average amount of potable water required for each land use type based on gallons per day (gpd) or acre feet per year (AFY). For example, a house designated as Residential Hillside (RH) uses approximately 728 gallons per day per lot. If there are 71 lots of RH, then this would mean that 51,668 gpd are used, or 57.9 AFY. Water duty factors are calculated based on statistically representative samples from water meters. The water duty factors used in this report are listed in Appendix B, and were obtained from Arroyo Grande's Urban Water Management Plan (2005, p. 5-4).

The preferred alternative option for 2030 focused on the Grand Avenue corridor. This option increased the units for single family residential, multifamily residential and mixed uses. This alternative also maximized infill development of vacant parcels. The commercial, landscaping, and government building categories were not altered, thus water projections from the Arroyo Grande Urban Water Management Plan (2005) were used. The total projected water usage for this development scenario is approximately 402 AFY (table 6).

Table 6 Water conditions for current and preferred alternative 2030.

\begin{tabular}{|c|c|c|c|}
\hline & Existing Conditions AFY & \begin{tabular}{|l|} 
Preferred \\
Alternative AFY
\end{tabular} & Preferred Alternative for AG Total \\
\hline SFR & 2318.5 & 158.17 & 2382.2 \\
\hline MFR & 476.7 & 5.97 & 482.6 \\
\hline Mixed Use & 186.7 & 143.14 & 329.8 \\
\hline Commercial* & 430 & 68.00 & 498.0 \\
\hline Landscape* & 215 & 34 & 249.0 \\
\hline Government* & 48 & -7 & 41.0 \\
\hline Total & 3674.8 & 402.28 & 4077.1 \\
\hline
\end{tabular}

Current demand was calculated from the existing conditions of land use at approximately 3,674 AFY. The preferred growth alternative for 2030 predicts that there will be approximately 4,077 AFY of water demand by the city. If no conservation measures take place and alternative water sources are not realized by 2030, then the water supply will remain at 3,674AFY and there could be a deficit of 381AFY (table 7). 


\begin{tabular}{|l|l|l|l|}
\hline \multicolumn{4}{|l|}{ Table 7: Current and future water conditions (AFY) } \\
\hline Supply (2010) & Current Demand** & Demand in 2030** & 2030 Difference (Supply-Demand) \\
\hline 3794 & 3674.8 & 4077.1 & -283 \\
\hline $\begin{array}{l}* \text { Todd Engineers, 2008 } \\
* * \text { Cal Poly graduate class, } 2009\end{array}$ \\
\hline
\end{tabular}

Target Water Usage

The goal is to achieve a normal standard of water usage. According to the City's water usage standards, $89.9 \%$ of the total water supply is considered normal, which is any usage less than or equal to 3,411 AFY. The difference between the projected water demand in 2030 and the normal standard target is about 666 AFY. To have the water supply equal to the water demand, this would require a reduction of $283 \mathrm{AFY}$. In order to achieve the target goal, the City must continue the use of water conservation methods and identify alternative sources of water supply. 


\section{Potential Greywater Savings in Arroyo Grande}

The potential greywater savings in Arroyo Grande are based on two assumptions: that $60 \%$ of potable water is used on yard irrigation (AG Urban Water Mangement Plan, 2005) and that greywater would replace $100 \%$ of irrigation water. The calculations were based on various rates of participation. If every single family residential home in Arroyo Grande used greywater, then a total savings of 1391 AFY would be saved this year. In 2030, a total of 1429 AFY would be saved (figure 3). As renters may not be as invested in making greywater alterations, calculations for owner occupied homes were also made. There are 4,528 owner occupied residential homes (OOR) in Arroyo Grande. Water savings were calculated if there was $100 \%$ participation in OOR (4,528 homes), 50\% (2264 homes), 25\% (1132 homes), 10\% (453 homes) and 1\% (45 homes) participation in OOR (figure 3).

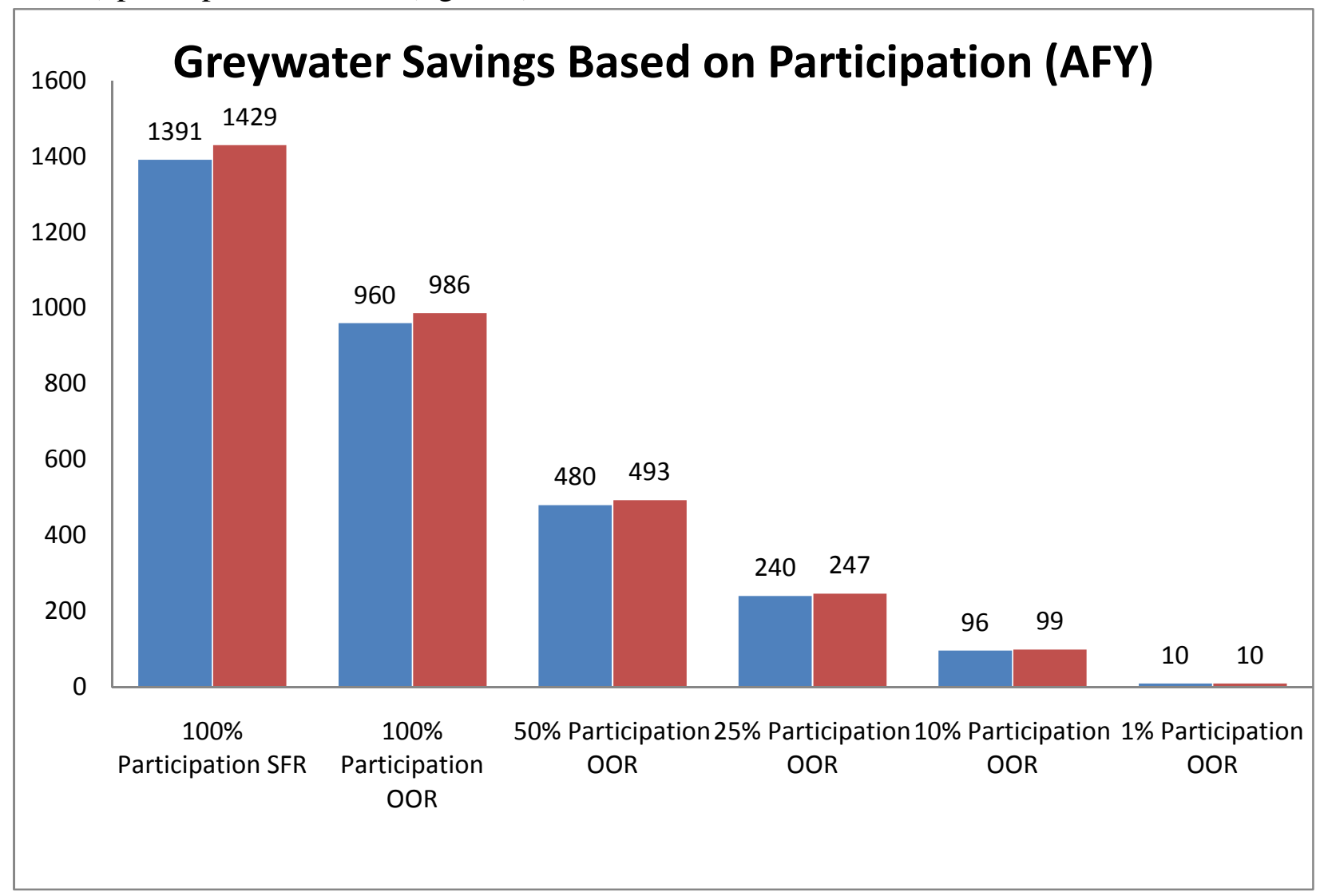

Figure 3 This chart indicates greywater savings for irrigation at different rates of user participation. Single family residential homes (SFR), and Owner occupied residential homes (OOR) were observed. Blue represents 2010, red represents 2030.

For best case scenario, greywater usage can save as much as 1391 AFY with 100\% participation of single family residential homes (2010). The goal is to drop below $90 \%$ water consumption (3414 AFY), which is ranked "normal" usage. In the best case scenario with greywater usage and indoor conservation, Arroyo Grande could reach 2284 AFY of total water consumption. This is equivalent to $62 \%$ water supply usage. 


\section{Education and outreach}

In order for greywater implementation to be successful in Arroyo Grande, both city officials and residents must be comfortable with embracing the idea of greywater reuse. This has been an accepted method of water conservation throughout the world, yet misinformation and stigmas often cloud the discussions on greywater reuse as a serious opportunity. This is rapidly changing for Californians, since the summer of 2009 the state of California legalized simple laundry and single fixture systems without a permit, where "for the first time, licensed professionals can legally help with the 1.7 million existing greywater systems in the state" (Ludwig, 2009). Now the legal framework supports the use of simple greywater systems, it is up to local cities to engage in public outreach to let it be known that greywater can be and should be used to conserve potable water supplies. Public outreach can be achieved by education pamphlets in water bills; manning booths at farmer's markets, festivals, or public events; introducing education programs in the public school system; and hosting workshops for residents who are looking for more in-depth knowledge about greywater.

Another issue with greywater acceptance has little to do with public knowledge the government body. Stenekes (2006) suggests that rhetoric about public acceptance of water reuse fails to address the heart of the issue, which is a lack of institutional change that provides a foundation for constructive public engagement. Failure to implement sustainable water reuse is not due to public rejection, but more along the lines of financial barriers, institutional conservatism, administrative fragmentation, and inadequate involvement of communities in planning. Although Stenekes is addressing issues with centralized water recycling infrastructure, similar barriers are presented with decentralized greywater systems. In order to achieve sustainable water conservation methods, it may require better coordination among agencies and integrated government policies. 


\section{Greywater Case Studies: Jordan, Arizona, \& Santa Barbara}

\section{Case Study Relevance}

Three case studies were chosen to illustrate how greywater can be implemented in policy and used on the ground by observing the Hashemite Kingdom of Jordan, the state of Arizona, and the city of Santa Barbara. As unique each setting appears, they all have the baseline issue of water scarcity in common. These case studies will illustrate lessons learned from each scenario.

\section{Jordan}

Potential drawbacks of installing greywater systems in a dense to semi-dense urban setting is the systems can require a large amount of space and have high construction costs when adding on to homes already built (Varghese, 2007). The most desirable and affordable method of greywater installation is from the beginning of home design and construction. However, Arroyo Grande is nearly at maximum build-out, so most residents that decide to partake in greywater reuse will have the option of building retrofit. Thus, Arroyo Grande is left with a situation where potential greywater systems would ideally fit in a small area with a low cost of installation. This scenario is similar to that of our first case study that takes place in the Hashemite Kingdom of Jordan.

Potable water scarcity is a global issue, and to gain a wider sense of the problem it is essential to study how other parts of the world are addressing issues of water shortage. The Hashemite Kingdom of Jordan is faced with the same predicaments as Arroyo Grande, except their cities are denser and their water shortage is more dire than the current conditions facing California's central coast. However, with potential seawater intrusion in its groundwater basins and the challenges of climate change, Arroyo Grande's future may not be dissimilar from the conditions of Jordan today. While the culture in Jordan is very different from that of Arroyo Grande, it is climatically similar with a Mediterranean and semi-desert climate. Faced with severe water shortage and poverty, this country has become conservative and creative with their water usage. On an average annual income of $\$ 8,000$ (Potter, 2007), the people of Jordan are successfully reusing greywater in their homes. This indicates that it is possible for affordable and compact greywater treatment to be used in Arroyo Grande. Four-barrel treatment systems of this kind have also been used throughout the Middle East and in Occidental, California (Krause, 2006).

\section{Casa del Agua - Arizona}

The Casa del Agua field study addresses how effective water conservation techniques can be for an average single family home in the United States. Tuscon's average annual rainfall totals to about 12 inches, which is about half the amount of rainfall in Arroyo Grande (NOAA, 2010). 
The Casa del Agua project is a relevant case study for Arroyo Grande because it addresses how an average American household can reduce water consumption with minimal behavioral changes. Water quantity and quality were analyzed. Five different greywater treatment systems were tested in this study, each modified from a previous system. All systems met water quality criteria for Arizona State. These types of greywater treatment systems would be ideal for Arroyo Grande residents who have space for a sump tank, two aquacells (2.1 square meters each), a sand filter (3 square meters) and a storage tank (3,025 L). Between greywater installation and water conservation appliances, the retrofit home achieved a $24 \%$ reduction in total water used, and a $47 \%$ reduction when compared to Tuscon residents.

\section{Santa Barbara - California}

Santa Barbara was the first city in the United States to permit greywater systems, giving the city a visionary history from which other California cities can learn. The study is relevant to Arroyo Grande because both cities are climatically and geographically similar, and are bound by California law. Santa Barbara participated in a study performed by the Department of Water Resources in 1996 that looked at the benefits, costs, and impacts of greywater reuse systems in single family residents. The case study in Santa Barbara showed that effluent was not harmful to soil health and that systems can be installed at an affordable rate. Santa Barbara has learned from experience that charging residents for single fixture permitted systems and placing strict standards on system design pushes people to illegally install greywater systems. Thus, when California loosened greywater law standards, it allowed people to hire professionals to install systems and receive sound information and advice provided by the City. Arroyo Grande may learn from Santa Barbara's experiences by keeping regulations to a minimum, streamlining the permit process, and making information readily available. 


\section{Greywater Use in Jordan - A Case Study}

\section{Country Setting}

The Hashemite Kingdom of Jordan consists of 89,342 sq km (34,494 sq miles) of land that borders Israel to the west, Syria on the north, Iraq and Saudi Arabia to the east and shares a small strip of the Red Sea to the south. It is estimated that the population consists of a mere 5,850,000 people (Department of Statistics, 2003). The economic condition of Jordan is dire, facing debt, poverty and unemployment. The population growth is at 2.7 percent and there is a widespread migration from rural to urban areas. Currently, 73 percent of the population is living in urban places, and it is expected to reach 80 percent by 2015 (Surani, 2003).

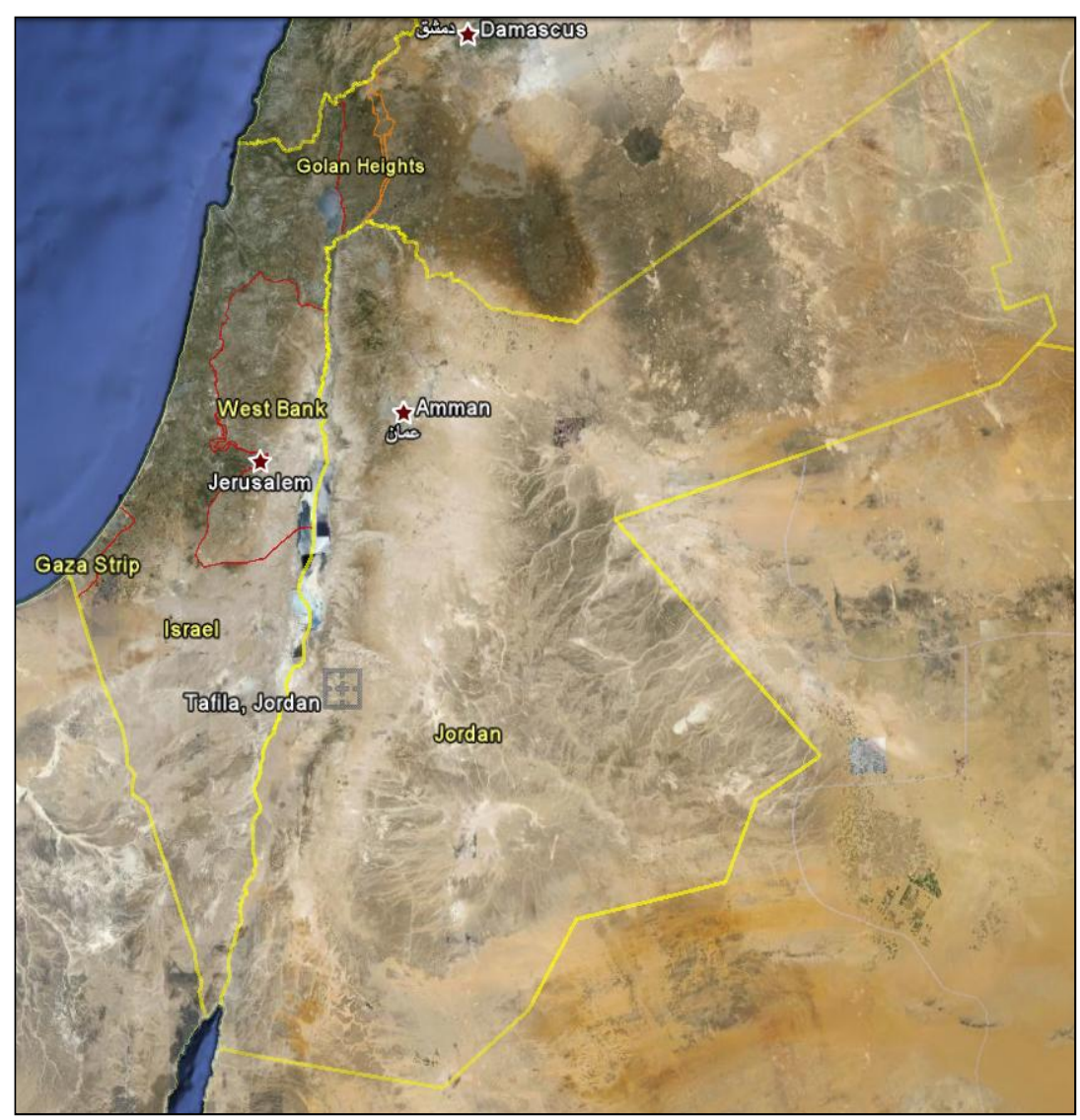

Source: Google Earth (2009).

\section{Water security}

Jordan's water crisis is recognized as having one of the world's most acute water shortages, placing it in the top ten of water poor countries. Freshwater supply sources come from damming and pumping of springs and wadis (ephemeral riverbeds), over-pumping aquifers, and exploiting fossil water. Freshwater scarcity is exacerbated by the lack of nearby fresh water sources and a lack of oil capital to pay for desalination plants, which puts Jordan at a further disadvantage in comparison to neighboring countries. In the year 2000, freshwater demand exceeded supply by 
$140 \%$ (Chesrown, 2004). In the mid 1990's each household was rationed a mere 22 gallons a day per household, compared to Saudi Arabia's 65 gpd per household and Israel's 78 gpd per household. In Jordan, there is an average of 9 persons per household (Surani, 2003). In the Middle East North Africa (MENA) region, up to $89 \%$ of freshwater resources are used for agriculture irrigation (Redwood, 2008).

Jordan is constantly pursuing alternative methods of supplying water to its people. During a workshop on Urban Agriculture in Gaza (1998), the International Development Research Corporation (IDRC) became aware that greywater reuse holds high potential for water conservation and directed funding to this area for further study. The workshop revealed that the people in Jordan were already constructing makeshift greywater systems, separating greywater from blackwater, and using this water on site for urban agricultural purposes. A USAID study team recommended the use of recycled water from wastewater treatment facilities and greywater practices be used on a large scale to create a non-conventional source of water supply. It was also noted that these alternative methods of water conservation will not satisfy the full demand, and thus imported water or desalination of seawater will be necessary (Chesrown, 2004). The Islamic Network on Water Resources Development and Management (INWRDAM) conducted a greywater study in Tafila, Jordan, and observed how safety, economics and policies were affected by the installation of small-scale systems.

\section{Greywater Reuse Project in Tafila, Jordan}

The Greywater Treatment and Reuse Project in Tafila, Jordan, were conducted by the InterIslamic Network on Water Resources Development and Management (INWRDAM) from May 2001 to April 2003. The goal of the project was to address the role of greywater reuse in poverty alleviation and educate policy makers and residents about the benefits of small scale greywater operations. This was achieved by the design and installation of greywater reuse systems in twenty-five households in Tafila. The objectives of the project were to increase the recovery of greywater in a safe and simple manner; reduce any negative externalities of greywater on the environment; improve gardening and permaculture practices; and to promote policy change toward greywater reuse in Jordan.

Government involvement performed at a level of data analysis, and included the Ministries of Public Works, Health and Water and Irrigation, Ministry of Agriculture (MOA), National Center for Agricultural Research and Transfer of Technology (NCARTT), Ministry of Water and Irrigation (MWI), and Water Authority of Jordan (WAJ). These governmental organizations were responsible for monitoring agricultural components of the project, conducting water and soil samples, and plant monitoring. An aspect that could be improved upon would be to increase the amount of government-community interaction, as there was little contact between the beneficiaries and these organizations. 


\section{Greywater System Design}

The greywater systems installed were designed for small-scale single family units that consisted of a four polyethylene barrel treatment kit (figure 4). The barrels are placed in a row, each performing its own function in the water treatment process. The first barrel acts as a primary treatment chamber where solid materials sink and separate from the floating materials, such as soap and grease. This barrel has a large cover that can be periodically opened to remove settled and floating material. The second and third barrels are filled with 3-4 cm size gravel where the anaerobic bacteria live on the surface of the gravel. These bacteria break down organic material, treating the water. After materials settle out from the first barrel, the water passes into the bottom of the second barrel. The water from the top of the second barrel enters the bottom of the third barrel. The treated water is moved to the last step, which is the storage tank. When this tank is full, a small water pump is switched on, and delivers water through a drip irrigation system. This simple primary treatment system can irrigate a garden of 20-30 fruit-bearing trees. The average retention time is approximately three days (Redwood, 2008).

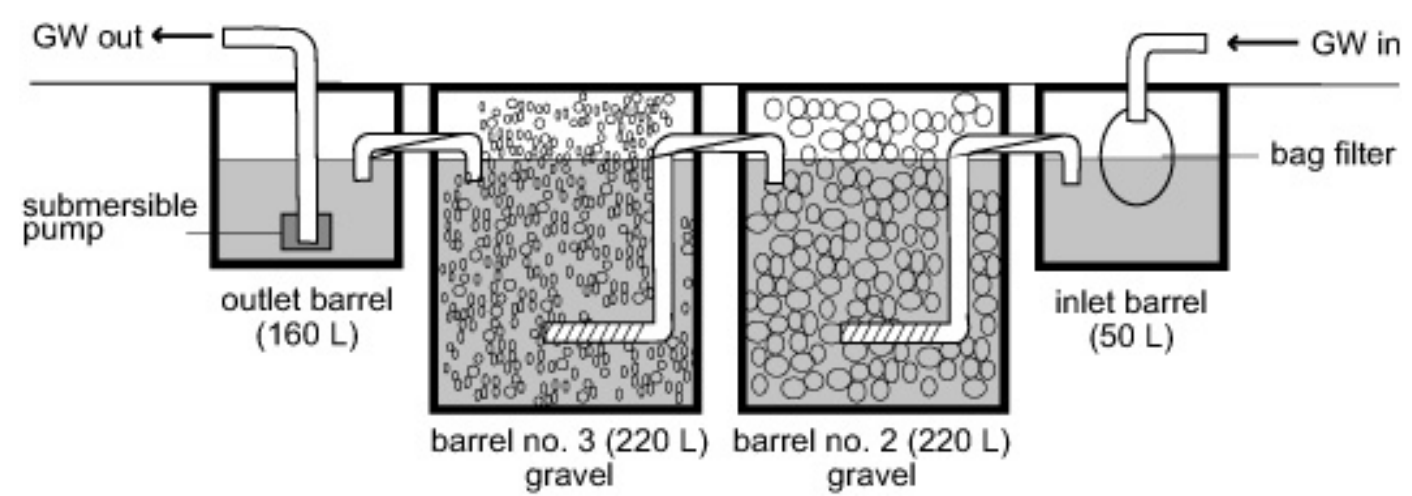

Figure 4 Four barrel treatment system. Source: http://www.idrc.ca/en/ev-152493-201-1-DO_TOPIC.html

The four barrel system effluent meets the standards of the World Health Organization guidelines, but has areas for improvement. The anaerobic bacteria that treat the water are organisms that survive and reproduce without the presence of oxygen. Instead of oxygen, they uptake compounds like sulfates and nitrates for energy, and their metabolic byproducts are in the form of hydrogen sulfide, which creates an odor (Norwalk, 2006). The advantage of using this method is that the entire treatment system is confined to a small space and the anaerobic process negates the need for electromechanical equipment, drastically reducing the cost of water treatment. As this system offers a cheaper alternative to water treatment, the cost of a system is approximately $\$ 400$ to $\$ 500$ per household, which is still more than most families can afford (Redwood, 2008). Thus, odor and cost are the two main social barriers that prevent people from adopting the four barrel water treatment method.

\section{Project objectives and results}

There were four main objectives of the greywater project in Tafila. These included: 
1. Increase greywater recovery and make it more convenient and safe to handle

2. Minimize environmental impacts associated with greywater reuse and ascertain whether greywater treatment is necessary and cost-effective

3. Improve gardening/permaculture practices

4. Promote changes in policies to encourage greater greywater reuse in Jordan

Increase greywater recovery and make it more convenient and safe to handle

The first objective of this project was to increase the amount of greywater reuse while making it convenient and safe to handle. About $90 \%$ of the participating homes were collecting greywater before the project, typically using the "bucket under the sink" method. This form of greywater reuse is common, and provides no water treatment before being reused for irrigation, creating negative environmental and health effects. The study consisted of twenty-five households where greywater and drip irrigation systems were installed. The domestic water consumption data collected for 50 selected households showed that 160-240 liters (42.3-63.4 gallons) of greywater is recovered for each household per day. Results found that the four barrel kits could handle greywater treatment for household sizes of 6 to 12 people, with an output of less than 500 liters (132 gallons) per day. All beneficiaries reported that the installed systems saved them time and labor, making greywater easier to use and manage.

\section{Minimize environmental impacts associated with greywater reuse and ascertain whether} greywater treatment is necessary and cost-effective

The second objective of the study was to reduce environmental impacts associated with greywater reuse and determine if greywater treatment is necessary and economically beneficial. On an ecological scale, the reuse of nutrient-rich greywater on crops is a beneficial application of wastewater when considering the alternative of directing waste into the watershed. Greywater can be a source of phosphorus and nitrogen, from laundry and kitchen water, respectively. These elements are beneficial for plant growth on crops, but can cause problems if dumped into surface waters, such as eutrophication. Another presumed positive environmental impact is the reduction in groundwater contamination from overloaded septic tanks.

Effluent quality was an area of concern, considering the potential salts that may negatively affect the soil for crops. To address environmental and economic concerns, habitual changes were encouraged. For example, organic soaps were created and marketed to reduce environmental impacts, which were made available at a lower cost than conventional detergents. Dish washing liquid and shampoo were products that residents were most likely to use. Potassium-based liquid detergents were designed and distributed to many parts of the country by the detergent company Zarka, but are not yet readily available on the market. Using simple screens and grease traps in the kitchen and washing dishes in one sink and rinsing them in another was also encouraged. 
The cost of the four-barrel system averaged to about $\$ 575$, and if you include greywater separation devices and irrigation it totals to approximately $\$ 750$. This is the equivalent to one month's income for a median-income family, making it unaffordable for impoverished residents. INWRDAM conducted a survey in 2003 to see how much people are willing to pay for this kind of system. Approximately $70 \%$ were willing to contribute some money to the cost of the system, where about $30 \%$ were unable to pay. As some beneficiaries are willing to shoulder the burden of cost for these greywater systems, there is a widespread sense of entitlement from community members that they should receive the system for free. Since the study, over 900 systems have been installed throughout Jordan at no cost. It is unlikely that neighbors of no-cost systems will pay for greywater systems out of pocket. This is a matter of concern because if potential beneficiaries do not associate a cost with the technology, then it may reduce a sense of ownership toward the system, which may affect the effort put forth in making the system perform successfully. In other words, if nobody pays for the system, then it may have no social value connected to it, which defeats the long term sustainability of the project.

\section{Improve Urban Agricultural Practices}

Urban agriculture is a rapidly increasing practice in Jordan. The capital of Amman contains a third of Jordan's population, and approximately one in six households (1.8 million people) grows their own fruits, vegetables and herbs in personal gardens (Alexander, 2008). Pitfalls of this practice are that urban farmers are using heavy doses of pesticides, fertilizers, and untreated wastewater. This poses potential negative effects on public health, soil quality, productivity, and other environmental factors. There are, however, many benefits to urban agriculture. Water shortage has caused an increase in food prices. Fresh water is being transported into urban areas in rapidly growing cities, and away from agricultural areas, putting pressure on food production. Increase of food prices further burdens the lower income residents, who are at greater risk of suffering from malnutrition and health problems. Urban agriculture is a direct method of combating these problems, and if it is used with safely treated wastewater, then food security can be achieved despite the pressures of water scarcity.

The Tafila greywater project addressed food security issues by increasing the effectiveness of greywater distribution with improved irrigation techniques, as well as identifying what types of crops (new or previously used) grow well locally that are tolerant of greywater irrigation (table 13). A major achievement for the improvement of agricultural practices was the installation of drip irrigation for all 25 households. Previously, residents were irrigating their crops using buckets of water from under the sink. Now, approximately half of the total land area is irrigated with primary treated greywater via drip systems, distributing treated water more effectively and less strenuously. 


\begin{tabular}{|l|l|}
\hline \multicolumn{2}{|l|}{ Table 13: Recommended crops for greywater irrigation in Tafila } \\
\hline Recommended crops for greywater use & Previous usage of crop \\
\hline Pistachio trees & New \\
\hline Artichoke & New \\
\hline Sudan grass & New \\
\hline Smooth leaf cactus & New \\
\hline Olive & Common \\
\hline Fig & Common \\
\hline Apricot & Common \\
\hline Apple & Common \\
\hline Citrus & Common \\
\hline Almond & Common \\
\hline
\end{tabular}

After irrigating with greywater, all of the residents noted an increase of production from their crops yields. However, the study team noted that agricultural practice has room for improvement. Areas that can be improved upon include soil management, plant protection and disease control, and appropriate plant species suitable for greywater irrigation. It is recommended that there be increased efforts to educate the residents about these areas of concern. There is also apprehension about long-term effects of greywater usage on soil quality, as there is little data available.

\section{Promote changes in policies to encourage greater greywater reuse in Jordan}

The study recognizes that the adoption of water reuse policy is crucial for future greywater participation. In order to simplify this process, the researchers provided the National Committee on Building Codes with a chapter on water reuse that applies building code to greywater connections. This chapter resulted in the formation of a technical advisory committee to review the recommended changes. The National Committee on Building Codes supported the notion of greywater systems in rural lands, but expressed concern about installing these systems in urban areas. This apprehension is due to the effect of greywater systems on municipal wastewater treatment facilities.

The proposed changes have not yet been accepted by the Ministry of Public Works and Housing. The subject of greywater had not yet been introduced to legislation, so a separate committee was formed to introduce this to legislation. More data was requested about the benefits and health risks of greywater systems. As progress may be slow, the introduction of greywater to policy makers has set the standard for future acceptance and adoption.

\section{Conclusion}

The greywater reuse project in Tafila has been revered as a success in many aspects, but also has areas for improvement. One of the greatest accomplishments of this project was that it raised awareness of greywater, educating residents and policy makers about the benefits of how and 
why these systems should be used. This boosted social acceptance of the simple four barrel treatment system, particularly when the government was providing the systems at no cost. Barriers to social acceptance are odor and price. Residents used the greywater systems in the study when they were provided, but were less willing or unable to pay for a greywater treatment system, particularly if their neighbors received their system for free. Greywater usage on home crops has also been shown to increase food security, a growing problem due to water scarcity which increases the cost of food. Primary treatment of greywater for irrigation is an improved method from the previous practice of using untreated wastewater on crops. Education about chemical application on crops is needed to reduce health and environmental hazards. From a policy perspective, a greywater technical advisory committee was formed to introduce greywater practice into law. Progress in the policy realm is slow, as there are health concerns and questions on how it will affect municipal wastewater treatment facilities. However, previous to this study, legislation had not been introduced to the concept of greywater policy, and it has piqued the interest of policy makers. The study team offered potential greywater policies to be adopted which are being reviewed by the technical advisory committee. This would set the standards for making greywater usage officially recognized, which would facilitate the adoption of simple wastewater treatment systems throughout Jordan, conserving water while increasing food security. 


\section{Arizona Case Study: Casa del Agua}

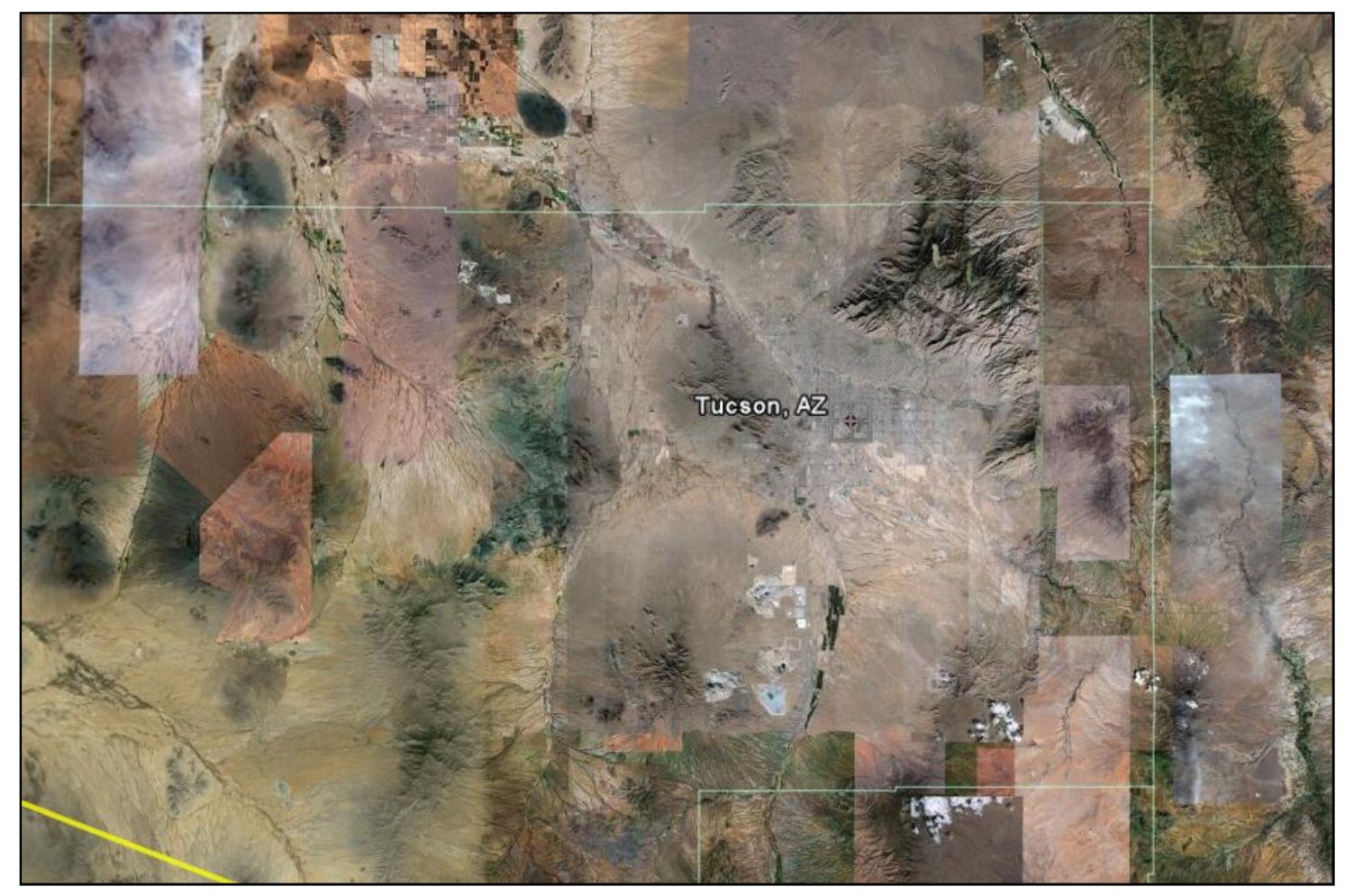

The Desert Research Unit of the Office of Arid Lands Studies (OALS) at the University of Arizona is a research group that focuses on urban water conservation. Casa del Agua is a residential home in Tucson that became available in 1984, which was used for research and demonstration purposes to look at various methods of water conservation, including greywater reuse, rainwater harvesting, plumbing retrofits, and xeriscaping. Studies have reported that unpermitted greywater use is common practice, usually applied with a simple hose or bucket with little to no pretreatment before application (Noah, 2002). Thus, there is an existing demand for greywater usage, and it would benefit the environment and people to make systems available. This project tested the hypothesis that residential water consumption could be significantly reduced in a single-family residential home without requiring major lifestyle changes. Casa del Agua was occupied by families from 1985 to 1999, and the water data results for the full 13 years were compiled and published by Martin Karpiscak in 2001. The objectives for Casa Del Agua were to record and calculate municipal water usage, greywater production and usage, and rainwater harvest usage; test water conservation plumbing devices; test research alternatives concerning greywater treatment; and educate interested parties about water conservation practicalities.

\section{Architectural augmentations}

Many alterations were made to the house to accommodate the listed objectives. For interior usage, greywater pipes were installed, separating it from blackwater in the master bathroom and 
kitchen. The kitchen garbage disposal and toilet water were directed to the sewer lines. Both greywater and harvested rainwater pipes were directed to the bathroom for toilet flushing, but these were added as an addition to existing water supplies.

For exterior modifications, the landscape was completely removed except for a drought-tolerant African Sumac tree. In the front yard, a new sloping driveway was installed, built with permeable river rock. A berm was erected to capture and retain rainwater on the premises and direct the flow of rainwater toward plants. In the back yard, a small turf grass area of $100 \mathrm{ft}^{2}$ was planted, which was located at the base of a sloped brick patio. The intension was to direct rainwater from the brick patio to the grass area. Xeriscaping was used wherever possible, and plants that required low water were planted with drip irrigation.

Interior water conservation applications included low-flow toilets (1 gallon per flush), a lowflow shower head, and faucet aerators in the bathrooms and one side of the kitchen sink. The garbage disposal side of the sink was directed straight into the sewage system due to high organic content. In 1988, new 1.6 gallon toilets were installed and in 1990, older 5 gallon toilets were installed in order to test low flow toilets.

Data collection was conducted via water monitoring devices throughout the house in addition to the city's water meter. Project meters were installed on all outside hose bibs, central monitoring compartment for irrigation of lawns and planter beds, the evaporative cooler, input and output of the greywater system, and rainwater usage was monitored. In 1986, additional water meters were installed on the hot and cold water lines to the washing machine. In 1987, similar water meters were installed on hot and cold lines for the kitchen sink and bathroom sinks.

\section{Overall water budget}

Three water sources supplied Casa del Agua, which included municipal water (69.7\%), greywater (19.9\%), and harvested rainwater (10.4\%). From January 1, 1986 to December 31, 1998, water usage in Casa del Agua totaled to 1,236,248 gallons of water, which amounts to approximately 260 gallons per household per day, or 86 gallons per day per capita. Average daily household use of municipal water during the time of the Casa del Agua project was 338 gpd based on a three person single family residence, and 113 gpdpc. The average household of Casa del Agua over the 13 year study was 181 gpd or 60 gpdpc. In 1995, the USEPA reported that the United States used an average of 183 gpdpc.

\section{Greywater system}

All greywater from the washing machine, bath tub, shower, bathroom sinks, and one side of the kitchen sink (the non-garbage disposal side) were directed into a 900-gallon collection tank. Nylon stocking filters were used to collect larger particles before water entered the collection tank, but later a stronger and reusable filter was installed. Later, one of the rainwater harvesting tanks was converted to a greywater tank because the single 900 gallon tank was not large enough 
to store all the greywater, and thus had to be dumped into the sewage line. When the tank filled to a certain water level, the sump pump was activated, and the greywater then entered the first of two aquacells. Aquacells consist of two three-hundred gallon galvanized metal tanks that contain water hyacinth plants that treat the water as they float on the surface. This water then overflows to a sand filter, which is then directed into a storage tank (Foster, 1988). This treated greywater was initially used for toilet flushing and landscape irrigation. Landscape irrigation became a dominant user of greywater, significantly reducing the demand for municipal water. In March of 1986 the greywater use in toilets was discontinued because the study's aim was shifted to how much water could be saved with low-flow toilets, and how much of a difference in municipal water usage is there between low flow and regular flow toilets. It was also noted that the entire supply of greywater could be stored and used for landscape irrigation on a seasonal basis (Karpiscak, 2001).

\section{Greywater Monitoring}

Greywater monitoring was accomplished through analog recording water meters and by manually measuring the depth of water in the storage tanks. The analog water meters were connected to the sump pump piping, and were the same kind of meters that were used to measure municipal water usage. The only alteration made in the distribution systems was in 1987, when one of the rainwater harvesting tanks was converted to a greywater storage tank. The storage tank water levels were measured with dipsticks marked by $10-\mathrm{mm}$ increments. Calculations for water volume were done by a spreadsheet program.

The amount of greywater produced and amount of greywater used was recorded. In the winter months it would not be uncommon for there to be more greywater produced than used because landscape irrigation would stop, and greywater would have to be directed to the sewage lines. No greywater was used from mid-July 1991 through April 1993 due to a large amount of stored harvested rainwater.

Water quality monitoring was accomplished through microbial, chemical, and physical analysis. This is discussed in further detail under Greywater Quality.

\section{Greywater treatment systems}

Over the duration of the project, the greywater treatment system was modified and improved upon to test the water quality of five different design methods. Each modification built upon the previous system, and is designed as follows:

System I: Once the sump tank was filled up to $50 \%$ capacity, the greywater was automatically pumped into the first aquacell (1,200-liter galvanized tank) that contained water hyacinths (Eichhornia crassipes). The tank depth was 0.58 meters with a surface area of 2.1 square meters. Overflow from this tank passed on to a second identical aquacell. Average retention time in the 
aquacells was around six days, and was aerated with a small pump typically used for fish tanks. Water passing from the second aquacell entered a sand filter through perforated PVC pipe submerged $5 \mathrm{~cm}$ below the surface. The sand filter was 0.038 meters in depth and had a surface area of 3 square meters. A variety of vegetables were grown in the sand filter to assist soil aeration. The treated greywater moved from the filter to the 3,025-liter storage tank. Water from the storage tank was then used for irrigation of lawns, shrubs, and trees by sub-surface drip irrigation (Gerba, 1995).

System II: The second system modified the first system by pumping greywater from the storage tank to the first aquacell at a rate of 1,893 liters/hour. A swimming pool purity unit provided copper ions for disinfection was installed in the recirculation line before it returned to the first aquacell. The increased flow of water required an overflow pipe attached to the second aquacell that bypassed the sand filter and lead directly to the storage tank (Gerba, 1995).

Systems III and IV: System II was modified by removing the water hyacinths and covering the aquacells with Styrofoam to prevent evaporation loss. System III used the same electronic pool purity unit as system II. System IV changed the brand of pool purity unit used. The new unit generated both copper and silver ions as a mode of disinfection (Gerba, 1995).

System V: Both aquacells and sand filter were removed and instead a 20-micron nominal porosity cartridge filter was used as the primary method of greywater treatment. All greywater was passed through the filter and moved into the storage tank (Gerba, 1995).

\section{Greywater Quality}

Water quality was analyzed by looking at microbial, chemical, and physical properties. Measurements of fecal and total coliforms before and after greywater treatment (sump and storage tanks, respectively) were collected once every two weeks. Several chemical and physical aspects were measured and collected at the same time and location as microbial samples. The measurements included $\mathrm{pH}$, turbidity, suspended solids and nitrates. 


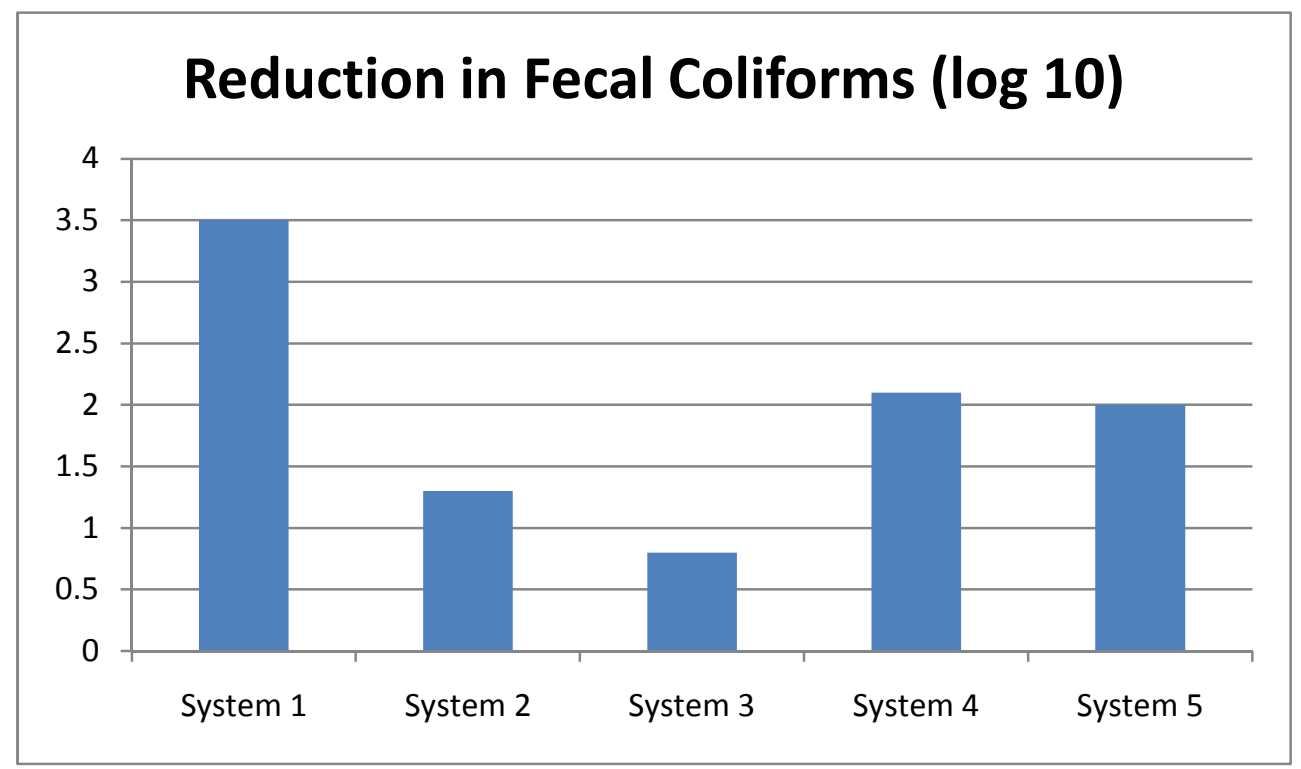

Figure 5 Reduction in fecal coliforms from sump to storage tank for each greywater system

Greywater treatment system I showed the lowest density of fecal and total coliforms compared to all other treatment systems (figure 5). Average removal of fecal coliforms was at $3.5 \log _{10}$ and total coliforms were at $2.9 \log _{10}$. System I was the second most effective in total coliform reduction compared to system 4 (figure 6). There was no change in $\mathrm{pH}$ from sump to storage, remaining slightly acidic at 6.7. Reduction in suspended solids, turbidity, and BOD were observed after greywater treatment (58\%, 94\%, and 97\%, respectively). Reduction of nitrates was not significant, but the average concentration before treatment was less than $2.0 \mathrm{mg} / \mathrm{liter}$.

Similar patterns of microbial reduction, decreases in suspended solids, and turbidity were observed for all other tested treatment systems.

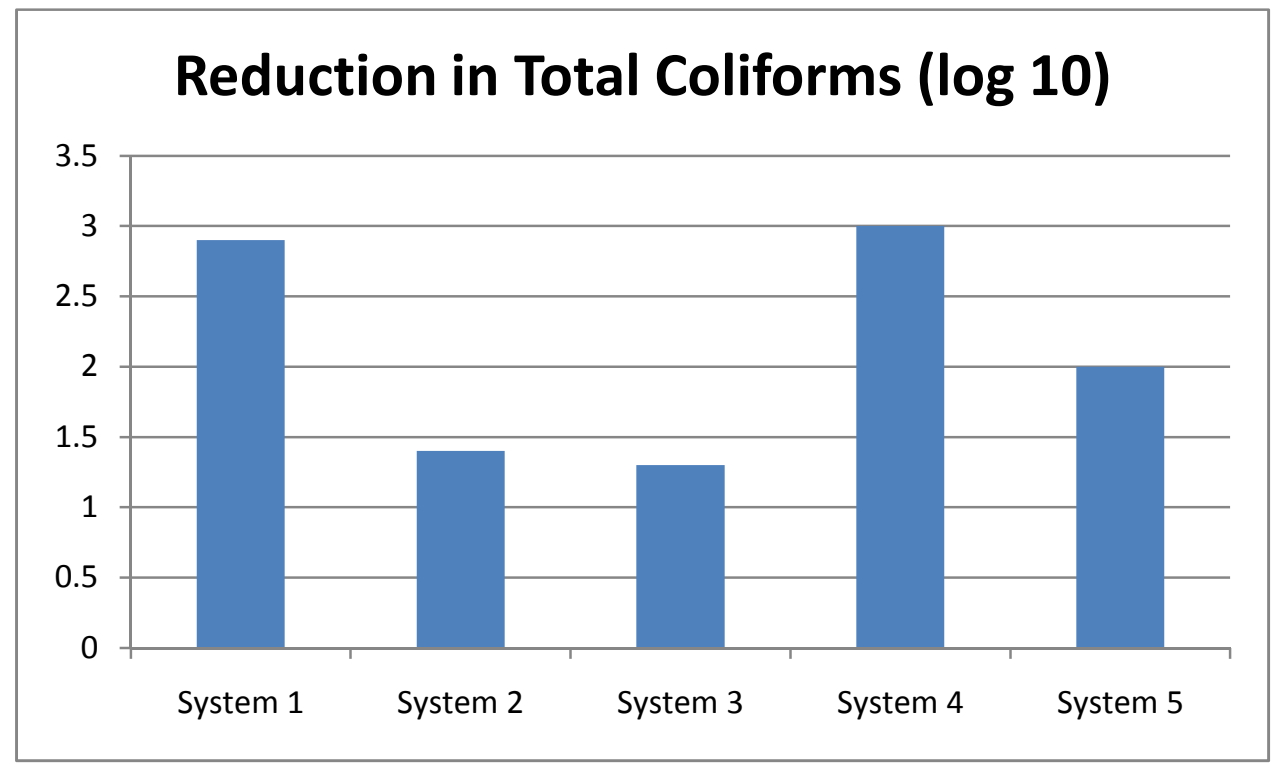

Figure 6 Reduction in total coliforms from sump to storage tank 
Greywater system II showed a higher concentration of indicator microbes in the storage tank than system I. Since the water pump was installed, the increase of flow caused greywater overflow into the storage tank, which was likely to be the principle reason why there were more indicator microorganisms than in System I. Fecal coliform removal was at $1.3 \log _{10}$ and total coliforms were at $1.4 \log _{10}$. The average reduction of suspended solids was $87 \%$ and turbidity was $95 \%$.

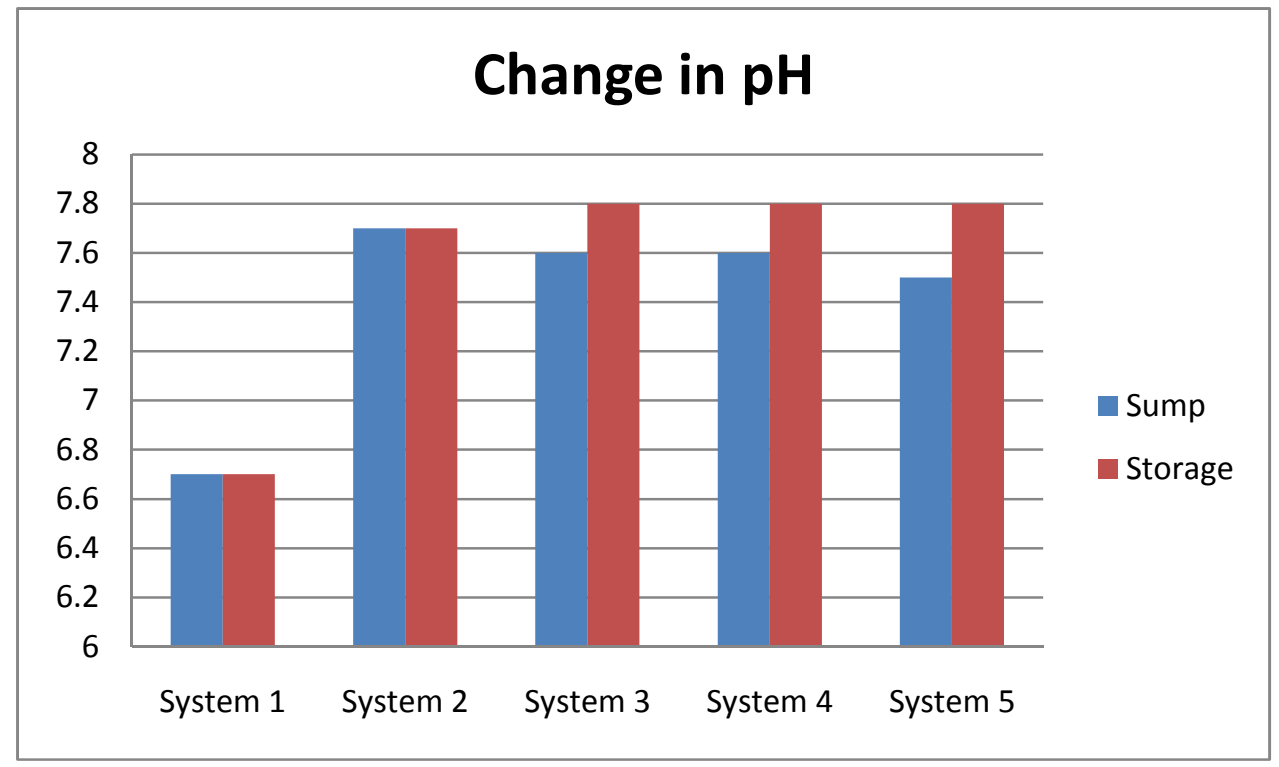

Figure 7 Change in pH from sump to storage tanks

After the water hyacinths were removed and the tanks were covered, the main source of greywater treatment for System III was the copper ion unit installed on the recirculation line. Similar average microbial reductions were achieved with this unit like in System II. Fecal coliform and total coliform reductions were averaged at $0.8 \log _{10}$. A smaller reduction in suspended solids and turbidity occurred when compared to system IV. The only difference between System III and IV was that system IV changed the pool purifier brand to one that had both copper and silver ion units. Both suspended solids and turbidity had lower average values in the sump when compared to the previous tests. The greatest average density of fecal coliforms was observed in treatment System V (5.2 $\log _{10}$ ), and the lowest concentration of suspended solids in the sump was observed with this system. 


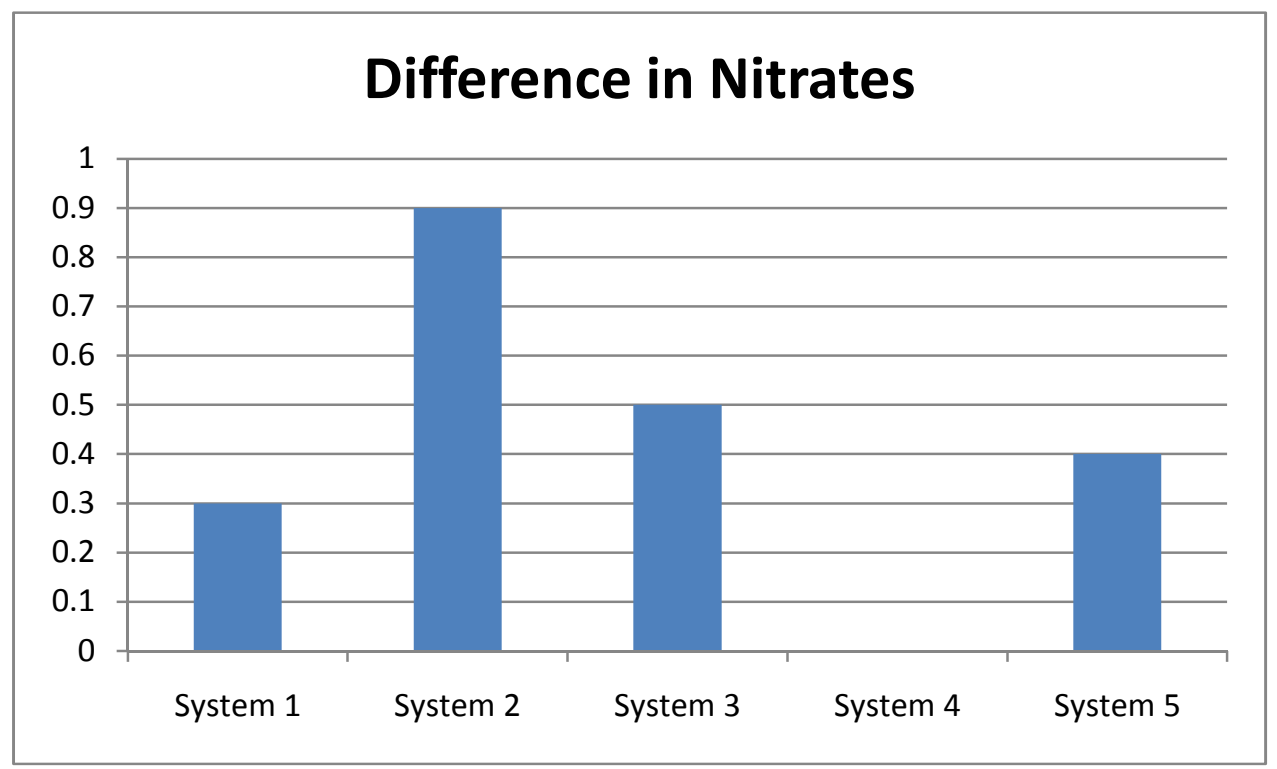

Figure 8 Change in Nitrates from sump to storage tank

\section{Conclusions}

Over 13 years of operation, total water conservation systems data in Casa del Agua displayed a $47 \%$ reduction in total municipal water demand when compared with the average water usage of a Tucson single family home. By the end of the study, greywater storage capacity increased to 5,700 gallons of water, which supplied $19 \%$ of the overall water budget at Casa. In comparison, rainwater harvesting supplied $11 \%$ of the water budget, and the remaining $17 \%$ was saved by using water conserving appliances and fixtures. Rainwater and greywater reuse for toilets was determined to be infeasible for this study because it required additional cleaning of the fixture due to materials found in the reused water.

Regarding water quality, the foremost public health concern with greywater reuse is the presence of harmful microorganism. This includes Escherichia coli, Salmonella sp., and a variety of other species of concern. Water hyacinths have been shown to significantly reduce biochemical oxygen demand (BOD), nitrogen, phosphorus, metals and trace organics. This makes it an ideal plant for raw and secondary treatment of residential wastewater. These water plants perform the best in warm climates, and are not as effective in cold climates. Greywater treatment system I in the study was most effective in reducing fecal coliform and total coliform levels.

Biochemical oxygen demand was only measured in System I, and water hyacinths reduced the BOD from $120 \mathrm{mg} /$ liter to $17 \mathrm{mg} /$ liter before sand filtration and $3.7 \mathrm{mg} /$ liter after sand filtration. Due to the lack of state and federal requirements for BOD reduction, the other systems were not tested for BOD reduction.

The addition of a copper ion swimming pool purity unit was an attempt to improve water quality beyond water hyacinth treatment. The release of copper into the water kills microorganisms; 
however, this was not as effective as the water hyacinths alone in reducing fecal and total coliforms. A reason this may be is due to the increased movement of water for recirculation purposes. This decreased detention time in the aquacells, reducing water treatment by the plants. In addition the overflow pipe bypassed the sand filter, which flowed directly to the storage tank mixing treated and untreated water. This is likely to be the cause of minimal reduction of microorganisms in system III, which was particularly ineffective in removing fecal and total coliforms. When the copper unit was replaced by a copper/silver unit in system IV, the microorganism removal rivaled that of system I.

System V filtered the greywater through a 20-micron nominal porosity cartridge filter, which removed fecal and total coliforms similar to systems I and IV. However, concentration of these organisms was high $\left(10^{5}\right.$ to $\left.10^{6} \mathrm{CFU} / 1000 \mathrm{ml}\right)$, which required filters to be changed frequently. Systems I, II, and IV were able to meet Arizona's turbidity standard of 5 NTUs. System II performed the best for reducing turbidity while system $\mathrm{V}$ performed the poorest.

Each system tested could meet Arizona's State regulations for nitrates, turbidity, and suspended solids. Additional treatment would be required to meet standards for total coliforms. The best performing greywater treatment system was system I based on reductions of fecal coliforms and percent turbidity removal. System IV would be better suited for cold climates where water hyacinths are not as effective. Ultimately, simple greywater treatment systems in this study can provide acceptable water quality for surface irrigation and toilet flushing, except additional treatment may be required for pathogenic microorganisms. Greywater holds great potential to reduce municipal water consumption, and the further development of guidelines and policies will increase the conservation of this dwindling resource. 


\section{The City of Santa Barbara - Greywater Case Study}

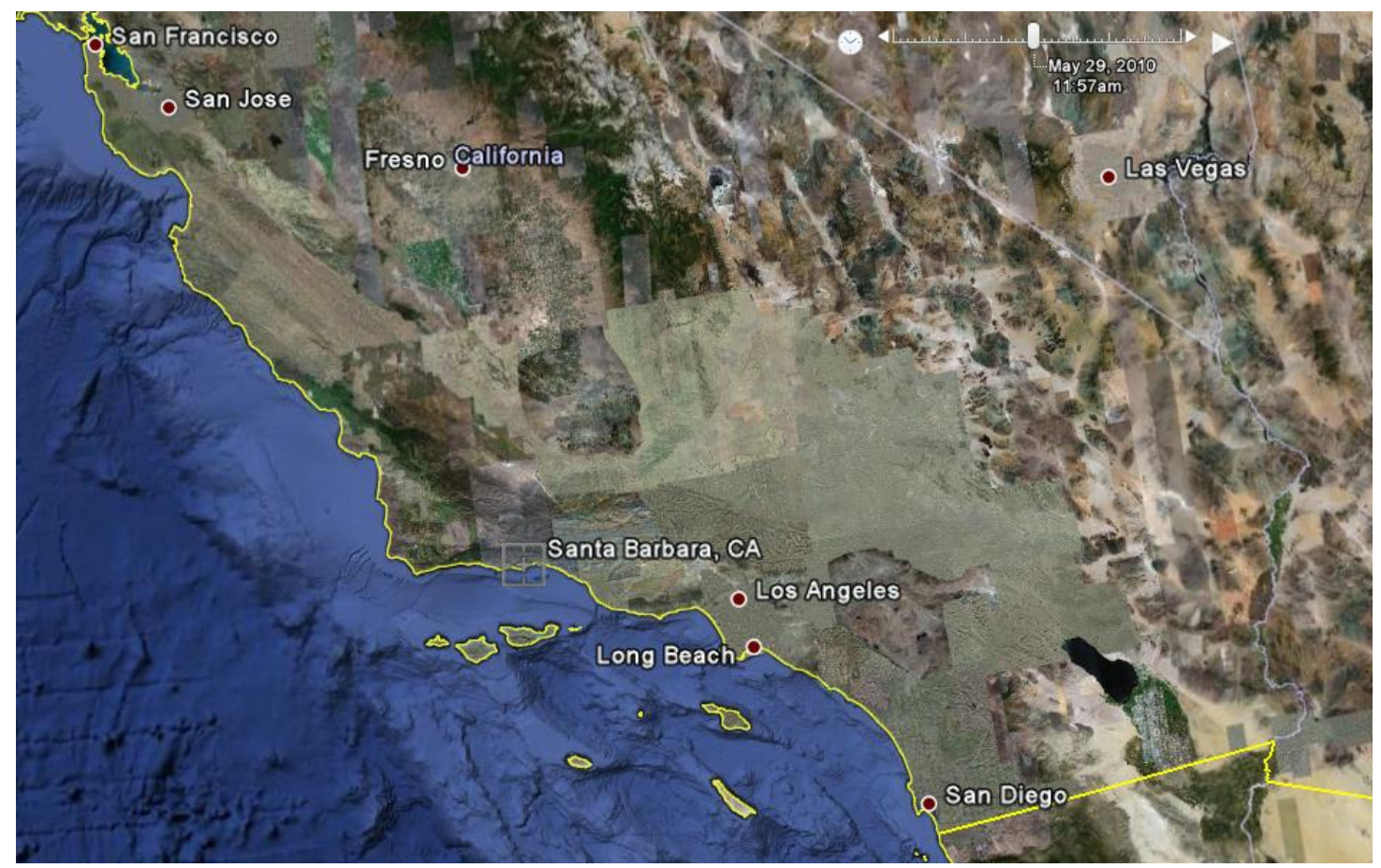

\section{Why Santa Barbara?}

Santa Barbara was selected for a greywater case study because the city has taken great strides to assist its residents with making educated choices about greywater usage and participated in a state-wide greywater study conducted by the Department of Water Resources (1999). Santa Barbara also has very similar climatic conditions to Arroyo Grande, both which are coastal communities whose weather is moderated by the proximity of the Pacific Ocean. Summers are warm with no precipitation and winters are cool and wet. The annual average precipitation of Santa Barbara (18.2 inches) is slightly higher than Arroyo Grande (17.7 inches). Santa Barbara's similar climate and shared state regulations make it a model city for greywater accessibility, outreach, and performance standards.

\section{CDWR case study}

The City of Santa Barbara participated in a state wide study conducted by the California Department of Water Resources with the intent of collecting data to analyze the benefits, costs and impacts of greywater reuse systems in single family homes. During the time of the study (1996), a mere three sites were able to participate in the project, as opposed to the anticipated ten, due to the inability to obtain local permits and meet other criteria of the study. Thus, the participants consisted of Santa Barbara, Danville, and Castro Valley. 
Santa Barbara city and county were the first to permit the use of greywater systems in California during the early 1990's due to severe drought. This was allowed as a way for residents to keep their landscapes alive. After drought conditions subsided, residents maintained interest in keeping their greywater systems in order, but the law dictated that greywater was only permitted during drought conditions. City officials have encountered so many legal barriers to citizen-installed greywater systems that only three permits were issued over a period of nine years. This does not, however, mean that people were not using greywater on their property, resulting in many illegal systems.

A main component to Santa Barbara's participation in the study was to increase the amount of baseline data that would support the development of future legalization of permits. The study was conducted over two years, and the test results were compiled. Soil and water quality tests measured $\mathrm{pH}$, Boron, Sodium, Chloride, Calcium, Magnesium, Specific Conductivity, and Sodium Absorption Ratio. Each of these factors is capable of affecting plant growth.

\section{Site description}

The study site is a 1,100 square foot home on a 6,900 square foot property that was rebuilt in 1992 to accommodate a low-tech greywater system. From November 1996 to June 1997 three people lived in the house, and after that two people lived in the house. The yard is landscaped with an organic vegetable garden, fruit trees and drought tolerant vegetation. Greywater piping is connected to the bathtub/shower, bathroom sink and washing machine. The system is gravity fed and requires no filter or storage tank. The irrigation is arranged into two irrigation zones that are alternated every 2-3 weeks. Each zone consists of irrigation tubing that is split multiple times using T-fittings. The water flows to perforated five gallon buckets that are buried in the ground surrounded by wood chips. The homeowners used Oasis laundry soap in the washing machine. All fruit trees responded positively to greywater irrigation except for a guava tree. In 1998, they began using Ultra 7 enzyme cleaning solution, a soap-less water treatment disk in the laundry. After the addition of this disk, the guava tree's health appeared to improve.

\section{Soil testing}

The Department of Water Resources collected soil samples from within six inches of the sub-surface irrigation line using standardized sampling and testing procedures. Water samples were collected from an outlet of the surge tank. While water samples provide good reference data, soil samples are the best indicators of how greywater will affect plants and soils. Thus, observations made were based on soil sample data. The soil and water samples were tested for Boron, $\mathrm{pH}$, Sodium, Chloride, Calcium, Magnesium, Specific Conductivity, and Sodium Adsorption Ratio. These were tested due to the affects they may have on plant growth. These chemicals varied greatly due to a variety of factors such as initial water quality coming into the home, personal habits of residents, and laundry soaps that were used.

The results for soil pH showed that greywater causes slightly alkaline conditions, meaning a pH above 7.1. Chemicals that increase $\mathrm{pH}$ are Sodium, Potassium, and Calcium. The normal range for $\mathrm{pH}$ is between 6.5 and 8.4, where a pH of 7 is neutral (pure water). Thus, it is recommended that gardeners avoid acid-loving plants in greywater-irrigated landscapes. 
The hardness of the water varied, from soft (concentration of $\mathrm{CaCO}_{3}<75 \mathrm{mg} / \mathrm{L}$ ) to moderate $(75-150$ $\mathrm{mg} / \mathrm{L})$ (USEPA, 1986). This is measured by looking at the concentration of Calcium Carbonate $\left(\mathrm{CaCO}_{3}\right)$, which hinders the capacity of water to lather with soap. Soft water is preferable to hard water because it does not clog irrigation lines or emitters.

Sodium levels were found to be at levels less than $69 \mathrm{mg} / \mathrm{L}$, which is a safe level for plants. Readings between 69 and $207 \mathrm{mg} / \mathrm{L}$ is considered to have "increasing problems," and any level above 207 $\mathrm{mg} / \mathrm{L}$ are considered to be severe Sodium levels according to the United Nations Food and Agriculture Organization (UFAO).

Specific Conductivity (SC) is also referred to as electrical conductivity (EC) is a measure of all dissolved salts in the water. The samples all fell within non-saline conditions, which was less than 2,000 micromhos/cm (Soil Survey Staff, 1993).

The Sodium Adsorption Ratio (SAR) is a measurement of whether a water source will reduce the infiltration rate of water in the soil. This is based on the concentration of Sodium, Calcium, and Magnesium. A high SAR will reduce the infiltration of water into the soil. Any SAR above 13 milliequivalents per liter (meq/L) yields soils that have little permeability and aeration. All SAR readings in the study were below 13 . The combined data of SAR and SC reveal that greywater will not cause infiltration or permeability issues in the soil structure.

Calcium (Ca) and Magnesium (Mg) levels in soil are essential macronutrients for plants, yet it may cause clogging of drip irrigation if these chemicals are found at high concentrations. All $\mathrm{Ca}$ and $\mathrm{Mg}$ levels were found to be normal. Chlorine $(\mathrm{Cl})$ and Boron $(\mathrm{B})$ are elements that can cause toxicity to plants at very low concentrations. All $\mathrm{Cl}$ and $\mathrm{B}$ levels were found to be within a low concentration that would not cause any problems.

Soil samples reflected that greywater irrigation poses no problems when testing for hardness, SAR, Chlorine, or Boron. The pH is always alkaline, and SC indicates non-saline conditions. Thus, greywater does not pose a threat to soil structure or quality for alkaline-loving plants.

\section{Water savings}

Since this was not a pressure-driven system, but a gravity fed system, the method of volume measurement was achieved by a tipping bucket. The bucket filled with greywater up to 1.5 gallons before tipping and being dispersed into the system. The number of tips was recorded on a digital counter which simply multiplied the number of tips by 1.5 gallons to get a volume measurement.

From November 1996 to March 1997, the total greywater use was 3.5 hundred cubic feet (hcf). From April 1997 to October 1997, the system used 12 hcf. The first winter, irrigation was not necessary, and the system was turned off for January and February. For the second winter, only 1 hcf was used. In 
1998, there was heavy rainfall, so the system was turned off from January through the end of March. From April to September in 1998, 8 hcf was used.

The estimated lifetime of this greywater system is 20 years, and the total water savings is approximately 190,740 gallons (0.6 AF, or $255 \mathrm{hcf}$ ). The total cost of the system was $\$ 1131$, and the water savings amounted to $\$ 893$, meaning the net cost to the homeowner over 20 years would be about $\$ 238$, or $\$ 12$ a year.

\section{Permitting}

Obtaining a permit from the City of Santa Barbara Building and Zoning division was not a simple process. Inspectors lacked knowledge about California greywater standards and there was confusion on who had jurisdiction to permit a greywater system. The Building Division referred the homeowners to the county's Environmental Health Department. After six weeks, the homeowners were informed by the EHD that their department had no jurisdiction for review. The permit process was completed in the Building Division, cost $\$ 80$ and the permit was granted in three days. The permitting process was an educational experience for the homeowners and the regulatory agency.

\section{Santa Barbara Greywater Permitting Today}

Today, greywater permitting in Santa Barbara has become one of the most clearly defined greywater processes in California. Arroyo Grande could emulate what Santa Barbara has done to increase the adoption of legal greywater systems and facilitate the approval process for single family residents. Santa Barbara makes it clear what regulatory agency has jurisdiction and what the steps are to obtaining a greywater permit. For the greywater systems that require a permit, the cost has been reduced from $\$ 80$ to $\$ 50$.

All the information needed to install a greywater system is available on the City of Santa Barbara's website under A Guide to Permitting a Single Family Graywater System. The process is broken into eight steps:

1. Determine if the project needs a permit

2. Assess the site to find the most appropriate greywater system

3. Design greywater system

4. If a permit is required, submit application for Plan Check from the City

5. Receive Plan Check approval and permit from the City

6. Start constructing system according to approved plans

7. Call City Building \& Safety Division to set up an inspection when trenches are open

8. Call City Building \& Safety Division to schedule a final inspection

\section{Lessons learned}

The Santa Barbara greywater monitoring study was useful when looking at soil quality, cost-benefit analysis, and the permitting process. As the chemical analysis of soil tests fluctuated over time, the concentrations always remained at healthy levels for alkaline-loving plants. This shows that greywater 
irrigation will not have detrimental effects on soil properties. The cost-benefit analysis for the greywater system revealed that over 20 years, the total water savings are approximately 190,740 gallons for the cost of $\$ 12$ a year. Greywater is not viewed as a catch-all solution to water demand problems, but plays a role in the ecological approach to water conservation. Lastly, the greywater permitting process at the time was inefficient and confusing for the regulatory agency and the homeowners. Because of this, thousands of homeowners installed illegal greywater systems in their homes for their yards. Today, Santa Barbara has improved upon the permit process by legalizing simple greywater systems and making the permit process clear with accessible information for those who are interested in installing greywater systems in their homes.

\section{Greywater Policy}

Greywater is a difficult subject for governing bodies to handle because it is something that cannot be regulated, measured, or controlled as readily as centralized municipal water sources. Greywater reuse is a decentralized method of water conservation that can significantly cut down on water demand of a municipal water source, but has become a contentious issue due to potential effects on public health, horticulture, and ecosystems. If greywater systems are designed and maintained properly, it can be a great attribute to conserving the city's water supply, reducing water bills, decreasing greenhouse gasses, taking pressure off septic and treatment facilities, and cycling water back into the ecosystem. Yet, these systems are difficult to regulate because each is unique due to home construction, soil type, topography, groundwater and other factors that play into the installation of greywater. Thus, many states and local bodies of government have taken a conservative approach on the use of greywater by outlawing its use altogether. Yet as people become more educated on water scarcity and the increasing cost of water, some residents take it upon themselves to install their own greywater systems that may or may not be safe. With the legalization of achievable greywater systems, the government is able to set system standards and embrace this method of water conservation. This also opens up a niche market for greywater specialists, which may encourage more businesses opportunities to come to Arroyo Grande. This section will discuss the "model" greywater policies that Arizona has adopted, how California is improving its greywater policy, and suggested measures for Arroyo Grande.

\section{Arizona's Greywater Law}

Arizona's approach to regulating greywater systems can be used as a model for other states that are facing the challenges of water shortage. Advantages to Arizona's greywater law are that there is a threetiered system that foresees risk impacts based on volume flow; it is concise with a more detailed booklet for further explanation; and the law requires end-state performance goals, not design specifics. This approach is ideal because it opens up the possibility of greywater installation in people's homes rather than making greywater systems difficult to legally attain.

The three tiered greywater system is follows as:

1. Greywater systems that process a volume flow that are less than 400 gallons per day that meet a list of achievable requirements are covered under a general permit that does not require a 
builder to apply for anything. This drastically increased Arizona's greywater compliance, and encourages homeowners to meet system standards. It also promotes professionals to install simple residential greywater systems instead of people attempting to clandestinely install their own systems that may not achieve baseline standards.

2. Greywater systems that process over $400 \mathrm{gpd}$, do not meet the baseline list of requirements, and/or fit the category of commercial, multi-family, and institutional systems require a permit.

3. Greywater systems that process over 3,000 gpd are dealt with on an individual basis.

This three-tiered approach has opened up the opportunity for most people to install greywater systems in their homes without a permit as long as they follow simple standards. Arizona's greywater law also avoids prescribing design specifics, and regulates greywater systems by setting performance goals. The advantage of this method is that it leaves room for technological innovation in greywater design, and these innovations over time will not outdate code standards. The only aspect regulators are concerned with is how well the greywater treatment system performs.

\section{California's Greywater Law}

For the past thirty years regulators have failed to support California greywater users, where only one in 10,000 people of the state's 1.7 million users have a permit (Ludwig, 2009). The legalization of simple systems without a permit has opened up a market for greywater specialists where people can hire professionals to install greywater systems in a safe and secure manner rather than having to do it themselves. They can also receive professional advice, assistance, and maintenance updates for those who already have systems installed. With a single change in State greywater law, it has brought an entire underground culture to the surface. This recent change in greywater policy is openly supported by Dr. Linda Rudolf, Chief Deputy Director for Policy and Programs in the California Department of Public Health, and Dr. Rufus Howell, Deputy Director of Center for Environmental Health at the California Department of Public Health.

The intent of California's greywater code is rooted in goals of water conservation, reducing unpermitted systems, and relieving stress on water treatment facilities. Regulated by the Department of Housing and Community Development (HDC), chapter 16A "Nonpotable Water Reuse Systems" under the California Plumbing Code defines the minimum requirements for installing greywater systems. California recently adopted emergency rulemaking actions that make it legal for residents to install greywater systems in response to drought and water shortages. California law was filed with the Secretary of State, and became immediately effective on August 4, 2009.

\section{Greywater Permitting}

There are three types of greywater systems recognized in California, which include the laundry fixture system, simple system and complex system. Construction permits and plans are required of all systems except laundry or simple fixture systems. The non-permitted systems must follow the conditions listed in section 1603A 1.1 as summarized below. 
Clothes washer system or single fixture systems are exempt from a construction permit if the system meets the following criteria:

1. Notification about the system has been provided to the enforcing agency regarding location and installation. Local governments, after a public hearing and enactment of an ordinance or resolution, may further restrict or prohibit greywater systems.

2. The design shall allow the user to direct greywater flow to irrigation, disposal field, or sewage system. The direction control shall be clearly labeled.

3. The greywater system does not include a connection to potable water supply and does not affect other building, mechanical, plumbing, or electrical components.

4. Greywater shall be maintained on the site from which it was generated

5. Greywater shall be directed or maintained on an irrigation or disposal field

6. Greywater may be released above ground if there is at least two inches of mulch, rock, soil, or some equivalent separation covers the release point.

7. Ponding or runoff is prohibited and shall be considered a nuisance

8. Greywater systems shall be designed to minimize exposure to humans and domestic pets

9. Water used to wash diapers shall be diverted to the sewer system

10. Greywater shall not contain hazardous chemicals

11. Exemption from a construction permit shall be deemed to grant authorization for any greywater system to be installed in a manner that violates other codes

12. An operation or maintenance manual shall be provided and remain in the building as long as the system is in use. If change of ownership occurs, new tenants must be notified that there is a greywater system on site.

Simple systems are defined as a system that has multiple fixtures and a volume flow of 250 gpd or less. These systems require a construction permit unless deemed exempt from an enforcing agency. The enforcing agency must consult with the local public water system before exemptions are granted. The enforcing agency is also responsible for approving the design criteria of the system. The simple system is applicable for an average home that has up to five bedrooms. The $250 \mathrm{gpd}$ mark is also used in New Mexico state standards, and represents the point to where engineering may be required for any larger volume flow. Below the 250 gpd volume flow, the design will be performance-based (CPC Title 24, part $5)$.

A complex system includes those which discharge a volume flow over $250 \mathrm{gpd}$ and will require a construction permit from the enforcing agency. The enforcing agency is required to consult with the local water distributor about the greywater system before granting an exemption for a permit. $A$ complex system is applicable to a very large single family home, a multi-family dwelling, or other similar occupancies. It is likely that the applicant will be required to submit design standards by an engineer, design professional, or any other person that is qualified to do so (CPC Title 24, part 5). 


\begin{tabular}{|l|l|}
\hline Table 14: Construction permit requirements for California greywater systems \\
\hline Type of System & Permit requirement \\
\hline Clothes washer system or single fixture system & $\begin{array}{l}\text { No construction permit required if conditions in } \\
\text { section 1603A 1.1 are met }\end{array}$ \\
\hline Simple system & $\begin{array}{l}\text { Permit and plans required unless exempt by an } \\
\text { Enforcement Agency }\end{array}$ \\
\hline Complex system & $\begin{array}{l}\text { Permit and plans required unless exempt by an } \\
\text { Enforcement Agency }\end{array}$ \\
\hline
\end{tabular}

Greywater systems that require a construction permit may also be subject to submittal of detailed plans about the project to verify that the system complies with state standards. The County of San Luis Obispo, abiding by state law, requires a construction permit and site plan for any greywater system that does not meet the single fixture system criteria. The construction permit for a any non-single fixture system cost $\$ 399.00$ (Personal communication with Barry Tolle, 5/10/10).

There are no current water quality standards for onsite treated greywater systems intended for outdoor usage. The main concern is that there is minimal human-greywater contact, which is why greywater usage requires subsurface drip irrigation. For indoor greywater usage, such as greywater being used to flush toilets, the California Department of Housing and Community Development (HCD) require effluent to meet Title 22 recycled water standards. HCD recognizes that these standards were not intended for onsite greywater treatment, but it is the best reference currently available. There is substantial research being directed at water quality effluent for indoor usage, and standards will likely be similar to those in Canada and New South Whales. Thus, the HCD will continue to work with the California Department of Public Health on certification and standardization of water treatment systems.

The updated California Plumbing Code has been improved from the previous standards in many ways. Prior to 1989, greywater systems were illegal. Post-1989, the greywater law standards were overzealous in mandating design specifics that did not function well and consequently, nobody obtained a permit. Permits for these greywater systems would often cost more than the installation and parts alone. The attempt to control greywater installation backfired by an increased occurrence of illegally installed greywater systems throughout the state. In 2009, California had 1.7 million greywater systems, and out of these only one in 10,000 obtained a construction permit (Ludwig, 2009). This reveals that there is a widespread interest and demand for greywater reuse in the state, and the health risks of these systems are so low that not a single greywater-transmitted illness has been documented.

\section{Arroyo Grande - Goals, Objectives and Policies}

The formation of goals, objectives and policies concerning water conservation is the first step on the public sector level to encourage greywater usage. The overarching goal for water policy in Arroyo Grande should be to maintain adequate water supply for urban, agricultural, and wildlife usage. This can only be achieved by reducing the current rate of water consumption by adopting sustainable practices. This requires minor changes in daily life, such as introducing low-flow toilets and other water conserving features in the home, but also requires cultural shifts in mindset about potable water supplies. Lawn irrigation, for instance, is estimated to use up to $60 \%$ of Arroyo Grande's water supply, which is not a 
reasonable use of a limited potable water supply. Therefore, the city has the ability to reduce this method of use by physically reducing the amount of turf grass in the city (i.e. Cash for Grass program), encouraging drought tolerant landscaping, or mandate that lawns can be irrigated with non-municipal water supplies. Using greywater for subsurface drip irrigation would be a sustainable way of keeping lawns green. Other approaches to encouraging greywater installation and usage is by adopting sustainable building mandates on all new housing construction. The best way to install dual-pipe greywater systems is from the initial design of the structure. Education and outreach is essential for public acceptance of greywater systems. There should also be incentives for people who want to install greywater in their home. In Australia, the government is providing rebates of up to $\$ 500$ for households to install rainwater tanks or greywater systems, which is a method that could also work in California. The city of Arroyo Grande has many opportunities to encourage greywater usage from a policy approach, and suggestions for these policies are listed as follows:

\section{Water Conservation Goals, Objectives, and Policies}

C/OS1 Adequate water supply for human, wildlife and agricultural usage for Arroyo Grande at build-out.

C/OS1.1 Reduced water and energy consumption and added sustainability measures in new and existing homes.

Objective 1: Reduce water usage per capita consumption

Policy 1: Single Family Residential homes shall be required to irrigate lawns with non-potable water sources OR apply artificial turf grass OR landscape with droughttolerant vegetation.

Policy 2: The City should "lead by example" by ceasing to irrigate public parks and lawns with municipal water sources and adopt the practice of landscaping with artificial lawn and/or drought-tolerant vegetation and/or irrigating with non-municipal water sources.

Objective 2: Adopt sustainable building mandates for all new housing construction.

Policy 3: Single Family Residential homes should include dual-pipe greywater installation.

Objective 3: Support ongoing awareness campaigns and outreach efforts to promote the responsible use of resources.

Program 1: The city shall provide educational opportunities about greywater systems. Public education can be achieved through public schools, street festivals, farmer's markets, and scheduled workshops. 
Objective 4: Offer additional incentive programs to make greywater usage more feasible and attractive

Program 2: A greywater rebate system encourages residents to install greywater reuse systems in their home. The government offers $\$ 400$ per greywater system, or half the cost of the purchase/installation, whichever is the lesser amount. 


\section{References}

Alexander, D. (2008). Surveying urban agriculture in Jordan. IDRC Project Number 97-0211.

Cain, N. (2003, November 18). California Can Slake its Thirst via Efficiency, Conservation.

Media Advisory, the Pacific Institute. Retrieved on May 17, 2010 from:

www.pacinst.org/reports/urban_usage/waste_not_media_release_final.doc

California Energy Commission. (2005). California's Water Energy Relationship. Retrieved May 2009, from California Energy Commission: http://www.energy.ca.gov/2005publications/CEC700-2005-011/CEC-700-2005-011-SF.PDF

California Plumbing Code (2007). Chapter 16A. Greywater definition.

California Wastewater Training and Research Center (2003). Onsite Wastewater Treatment System Repair of Failure/Malfunction Survey. California State University, Chico.

Chesrown, S. (2004). Jordan Valley Preliminary Land Use Master Plan Project. Ministry of Water and Irrigation, Jordan Valley Authority. United States Agency for International Development (USAID). Volume 1 of 5.

City of Santa Barbara Building and Safety Division. Water Resources Division. A guide to Permitting a Single Family Greywater System.

Conservation and Use in Agriculture: http://www.wca-infonet.org/servlet

Cooley, H.; Christian-Smith, J.; Gleick, P.H., Allen, L. Cohen, M. (2009). Understanding and reducing the risks of climate change for transboundary waters. Pacific Institute in cooperation with the United Nations Environment Programme.

Davis, G. Nichols, M., Spear, M. (2003). California's Groundwater Bulletin 118. State of California The Resources Agency Department of Water Resources.

Department of Statistics (2003). The Hashemite Kingdom of Jordan population and general housing census. Website: http://www.dos.gov.jo/sdb_pop/sdb_pop_e/inde_o.htm.

Development Planning and Management Network (2004). Post project evaluation of greywater treatment and reuse project in Tafila, Jordan.

Finley, S., Barrington, S., Lyew, D. (2009). Reuse of Domestic Greywater for the Irrigation of Food Crops. Water Air Soil Pollution 199:235-245. DOI 10.1007/s11270-008-9874-x 
Foster, K.E., Karpiscak, M.K., Brittain, R.G. (1988). Casa del Agua: A residential water conservation and reuse demonstration project in Tucson, Arizona. Water Resources Bulletin. 24(6) 1201-1206.

Ferguson, J. (2009). SUBSTITUTING RESIDENTIAL RAINWATER HARVESTING AND GREYWATER REUSE FOR PUBLIC WATER SUPPLY: TOOLS FOR EVALUATING THE PUBLIC COST A Thesis, California Polytechnic State University, San Luis Obispo. Master of Science in Architecture.

Gerba, C. P., T. M. Straub, J. B. Rose, M. M. Karpiscak, K. E. Foster, and R. G. Brittain, 1995. Water Quality Study of Graywater Treatment Systems. Water Resources Bulletin 31(1): 109116.

Gleick, P.H. (2000). Water: the potential consequences of climate variability and change for the water resources of the United States. Pacific Institute for Studies in Development, Environment, and Security.

Gleick, P.H. (2003). Waste Not, Want Not: The Potential for Urban Water Conservation in California. Pacific Institute for Studies in Development, Environment, and Security.

Godfrey, S., Labhasetwarb, P. Wateb, S. Greywater reuse in residential schools in Madhya Pradesh, India- A case study of cost-benefit analysis. Resources, Conservation and Recycling. 53:287-293.

Goldman, M., Gilad, D., Ronen, A., Melloul, A. (1991). Mapping of seawater intrusion into the coastal aquifer of Israel by the time domain electromagnetic method. Institute for Petroleum Research and Geophysics.

Gross (2005) Environmental impact and health risks associated with greywater irrigation: a case study. Water Science and Technology. Vol 52 No 8,pp. 161-169.

Heberger, M.; Cooley H.; Herrera, P.; Gleick, P.H.; Moore, E. (2009). The impacts of sea-level rise on the California Coast. California Climate Change Center.

Hespanhol, I. (2003, May). Wastewater as a Resource. Retrieved May 2010, from Water

Hodgson, M. (November 11, 2009). AG Declares Moratorium. Santa Maria Times.com. http://santamariatimes.com/news/local/govt-and-politics/article_014a481a-cf5c-11de-9e6f$001 \mathrm{cc} 4 \mathrm{c} 03286 . \mathrm{html}$

Hodgson, M. (April 25, 2010). Arroyo Grande extends development moratorium. Santa Maria Times.com. Retrieved May 20, 2010. http://www.santamariatimes.com/news/local/govt-andpolitics/article_47d7175e-5030-11df-ad34-001cc4c03286.html 
Hollenbeck, John R. (October 23, 2009). Nacimiento Water Project. http://www.slocounty.ca.gov/Assets/PW/NacProject/Press+Release+091023.pdf

Karpiscak, M.K., France, G.W., DeCook, K.J., Brittain, R.G., Foster, K.E., Hopf, S.B. 2001. Casa Del Agua water conservation demonstration house 1986 through 1998. Journal of the American Water Resources Association. 37(5): 1237-1248.

Krause, G. (2006). Occidental Greywater. http://www.appropedia.org/Occidental_greywater Ludwig, A. (2009). CA BSC greywater standards testimony from Art Ludwig. Oasis Designs. http://www.oasisdesign.net/greywater/law/california/artBSCpresentation.htm

Ludwig, A. (2009). Grey Water Information Central. Website: http://oasisdesign.net/

Morrison, J. (2009). Water Scarcity and Climate Change: Growing risks for Businesses and Investors. A Ceres Report, Authored by the Pacific Institute.

Noah, M. (2002). Greywater use still a grey area. Journal of Environmental Health. Vol. 64.

NOAA (2010) http://www.wrh.noaa.gov/twc/climate/tus.php

Norwalk Wastewater Equipment Company, Inc. (2006). Identification of wastewater organisms. Website: http://www.norweco.com/html/lab/Identify.htm

Nowroozi, A., Horrocks, S., Henderson, P. (1999). Saltwater intrusion into the freshwater aquifer in the eastern shore of Virginia: a reconnaissance electrical resistivity survey. Journal of Applied Geophysics, 42(1), 1-22.

Ogren, Paavo (2009). SLO County Nacimiento Water Project General Information. http://www.slocounty.ca.gov/PW/NacWP/General_Project_Information.htm

Ottosson, J. and Stenstrom, T.A. (2002). Growth and reduction of microorganisms in sediments collected from a greywater treatment system. Water and Environmental Microbiology, SMI, Swedish Institute for Infectious Disease Control, Solna, Sweden2002/308.

Potter, R.B., Darmame, K., Barham, N. Nortcliff, S. (2007). An Introduction to the Urban Geography of Amman, Jordan. Geographical Paper no. 182. Pp. 18.

Redwood, M. (2008). The application of pilot research on greywater in the Middle East North Africa Region (MENA). International Journal of Environmental Studies. Vol. 65, No. 1, 109117. 
Redwood, M. (2010) Introduction: Greywater use in the Middle East: the story so far. International Development Research Center. http://www.idrc.ca/en/ev-152491-201-1DO_TOPIC.html

Schlein, L., De Capua, J., Kruger, S. (2007). For humanity's sake, developing world must prepare for soaring urbanization. UN Population Fund, City Mayors Society.

SLO Greenbuild (2009). San Luis Obispo Guide to the Use of Graywater.

Soil Survey Division Staff. 1993. Soil survey manual. Soil Conservation Service. U.S. Department of Agriculture Handbook 18.

South SLO County Sanitation District (2008)

http://sslocsd.org/index.php?option=com_content\&view=article\&id=35\&Itemid=171

Stenekes, N. (2006). Risk and Governance in Water Recycling: Public Acceptance Revisited. Nyree Stenekes Hal K. Colebatch T. David Waite Nick J. Ashbolt University of New South Wales Science, Technology and Human Values. Vol 32 no. 2 March 2006, 107-134

Surani, E. (2003). Research Influence on Policy: The greywater reuse case of Jordan. IDRC, CRDI.

Todd Engineers (2009). Annual Report of the Northern Cities Management Area.

Travis, MJ; Wiel-Shafran, A., Weisbrod, N., Adar,E., Gross, A. (2010). Greywater reuse for irrigation: Effect on soil properties. Sci Total Environ. 408 (12): 2501-2408.

Initial statement of reasons for proposed emergency standards of the Department of Housing and Community Development regarding the 2007 California Plumbing Code (CPC) California Code of Regulations, Title 24, Part 5.

http://www.hcd.ca.gov/codes/shl/ISOR_Emerg_Ch16A_7-1-09.pdf

US Census Bureau (2000). Census 2000 Demographic Profile Highlights

http://factfinder.census.gov/servlet/SAFFFacts?_event=\&geo_id=04000US06\&_geoContext=0 1000US $\mid 04000 U S 06 \& \_s t r e e t=\& \_$county $=\& \_c i t y T o w n=\& \_$state $=04000 U S 06 \& \_z i p=\& \_l a n g=e$

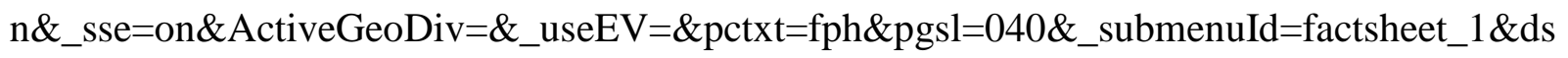
_name=ACS_2008_3YR_SAFF\&_ci_nbr=null\&qr_name=null\&reg=\&_keyword=\&_industry

U.S. E.P.A. (1986). Quality Criteria for Water 1986 [The Gold Book]. Web:

http://www.epa.gov/waterscience/criteria/goldbook.pdf 
Urban Water Management Plan (2005). City of Arroyo Grande, 2005 Update. Adopted March $14,2006$.

Varghese, J.K. (2007). Effects of the Implementation of Grey Water Reuse Systems on Construction Cost and Project Schedule. A Thesis, Texas A\&M University.

Whitney, A., Bennett, R., Carvajal, C., Prillwitz, M. (1999). Monitoring Greywater Use: three Case Studies in California. California Department of Water Resources

Xue, Y., C. Xie, J. Wu, P. Liu, J. Wang, and Q. Jiang (1995). A Three-Dimensional Miscible Transport Model For Seawater Intrusion in China, Water Resource Res., 31(4), 903-912.

\section{Appendix A}

Restrictions and measures for water supply conditions of the normal, moderate, severe, and critical tiers as stated in the Arroyo Grande municipal code:

13.05.020 Normal water supply conditions.

During normal water supply conditions, the following restrictions and measures shall be in effect:

A. Outdoor water use for washing vehicles, boats, paved surfaces, buildings and other similar uses shall be attended and have hand-controlled water devices, typically ineluding spring loaded shutoff nozzles.

B. Outdoor irrigation resulting in excessive gutter runoff is prohibited.

(Ord. 540 § 1, Exh. A (part), 2003)

13.05.030 Moderately restricted water supply conditions.

During moderately restricted water supply conditions, the following restrictions and measures shall be in effect:

A. Outdoor water use for washing vehicles, boats, buildings or other similar uses shall be attended and have hand-controlled watering devices, typically including spring-loaded shutoff nozzles.

B. Use of water which results in excessive gutter runoff is prohibited. 
C. No water shall be used for cleaning driveways, patios, parking lots, sidewalks, streets, or other such uses except as found necessary by the city to protect the public health or safety.

D. Outdoor Irrigation.

1. Outdoor irrigation is prohibited between the hours of ten a.m. and four p.m.

2. Irrigation of private and public landscaping, turf areas and gardens is permitted at even-numbered addresses only on Mondays and Thursdays and at odd-numbered addresses only on Tuesdays and Fridays. No irrigation of private and public landscaping, turf areas and gardens is permitted on Wednesdays. Irrigation is permitted at all addresses on Saturdays and Sundays however, in all cases customers are directed to use no more water than necessary to maintain landscaping.

E. Use of potable water for compaction or dust control purposes in construction activities is prohibited.

(Ord. 540 § 1, Exh. A (part), 2003)

13.05.040 Severely restricted water supply conditions.

During severely restricted water supply conditions, the following restrictions and measures shall be in effect:

A. Use of water which results in excessive gutter runoff is prohibited.

B. Outdoor Water Use--Except Irrigation.

1. No water shall be used for cleaning driveways, patios, parking lots, sidewalks, streets or other such use except where necessary to protect the public health and safety;

2. Outdoor water use for washing vehicles shall be attended and have handcontrolled watering devices, typically including spring-loaded shutoff nozzles.

C. Outdoor Irrigation.

1. Outdoor irrigation is prohibited between the hours of ten a.m. and four p.m.

2. Irrigation of private and public landscaping, turf areas and gardens is permitted at even-numbered addresses only on Mondays and Thursdays and at odd-numbered addresses only on Tuesdays and Fridays. No irrigation of private and public landscaping, turf areas and gardens is permitted on Wednesdays. Irrigation is permitted at all addresses on Saturdays and Sundays however, in all cases customers are directed to use no more water than necessary to maintain landscaping.

D. Emptying and refilling swimming pools and commercial spas is prohibited except to prevent structural damage and/or to provide for the public health and safety.

E. Use of potable water for soil compaction or dust control purposes in construction activities is prohibited.

(Ord. 576 § 3, 2005; Ord. $540 \S 1$, Exh. A (part), 2003) 


\subsubsection{Critical water supply conditions.}

In addition to the conditions specified in Section 13.05 .040 , the following restrictions and measures shall be in effect during critical water supply conditions:

A. Outdoor irrigation of private or public landscaping, turf areas and gardens is prohibited.

B. Outdoor water use for washing vehicles is prohibited except at a public car wash facility.

The city council may also impose any water-rationing requirements as it deems appropriate to protect public health, safety, welfare, comfort and convenience.

(Ord. $540 \S 1$, Exh. A (part), 2003)

\section{Appendix B}

\begin{tabular}{|l|l|}
\hline \multicolumn{2}{|c|}{ Water Duty Factor } \\
\hline Land use & gpd per lot \\
\hline Residential & 728 \\
\hline Residential Estate (RE) & 728 \\
\hline Residential Hillside (RH) & 728 \\
\hline Rural Residential (RR) & 425 \\
\hline Residential Suburban (RS) & 350 \\
\hline Single-family Residential (SF) & 350 \\
\hline Village Residential (VR) & 250 \\
\hline Condominium Townhouse (MF) & 250 \\
\hline Multifamily Apartment (MFA) & 250 \\
\hline $\begin{array}{l}\text { Multifamily Very High Density } \\
\text { (MFVH) }\end{array}$ & \\
\hline
\end{tabular}




\begin{tabular}{|l|r|} 
Planned Development (PD) & 500 \\
\hline Mixed Use & 0 \\
\hline Industrial Mixed Use (IMU) & 210 \\
\hline Traffic Way Mixed Use (TMU) & 210 \\
\hline Village Core Downtown (VCD) & 210 \\
\hline Village Mixed Use (VMU) & 210 \\
\hline Gateway Mixed Use (GMU) & 210 \\
\hline Fair Oaks Mixed Use (FOMU) & 210 \\
\hline Highway Mixed Use (HMU) & 210 \\
\hline Office Mixed Use (OMU) &
\end{tabular}

*Agricultural use is not included as water consumption for this land use is based in unmetered wells

\section{Appendix C}

\begin{tabular}{|c|c|c|c|c|c|}
\hline \multicolumn{6}{|l|}{2010} \\
\hline \multicolumn{2}{|c|}{ Single Family Residential } & \multicolumn{2}{|l|}{ Multi Family Residential } & \multicolumn{2}{|l|}{ Mixed Use } \\
\hline Category & $\mathrm{AFY}$ & Category & AFY & Category & $\mathrm{AFY}$ \\
\hline $\begin{array}{l}\text { Residential } \\
\text { Estate (RE) }\end{array}$ & 1.6 & $\begin{array}{l}\text { Condominium } \\
\text { Townhouse (MF) }\end{array}$ & 348.6 & $\begin{array}{l}\text { Traffic Way } \\
\text { Mixed Use (TMU) }\end{array}$ & 14.8 \\
\hline Residential Hillside & (RH) & $\begin{array}{l}\text { Multifamily Apartment } \\
\text { (MFA) }\end{array}$ & 97.5 & $\begin{array}{l}\text { Village Core } \\
\text { Downtown (VCD) }\end{array}$ & 12.0 \\
\hline $\begin{array}{l}\text { Residential } \\
\text { Suburban (RS) }\end{array}$ & 91.4 & $\begin{array}{l}\text { Multifamily Very High } \\
\text { Density (MFVH) }\end{array}$ & 30.5 & $\begin{array}{l}\text { Village Mixed } \\
\text { Use (VMU) }\end{array}$ & 29.4 \\
\hline $\begin{array}{l}\text { Rural Residential } \\
\text { (RR) }\end{array}$ & 340.6 & $\begin{array}{l}\text { Planned Development } \\
\text { (PD) }\end{array}$ & 691.6 & $\begin{array}{l}\text { Gateway Mixed } \\
\text { Use (GMU) }\end{array}$ & 10.4 \\
\hline $\begin{array}{c}\text { Single-family } \\
\text { Residential (SF) }\end{array}$ & 1100.8 & & & $\begin{array}{l}\text { Fair Oaks Mixed } \\
\text { Use (FOMU) }\end{array}$ & 30.1 \\
\hline $\begin{array}{l}\text { Village Residential } \\
\text { (VR) }\end{array}$ & 34.5 & & & Highway Mixed & 19.5 \\
\hline
\end{tabular}




\begin{tabular}{|l|r|l|l|l|r|}
\hline & & & & Use (HMU) & \\
\hline $\begin{array}{l}\text { Planned } \\
\text { Development (PD) }\end{array}$ & 691.6 & & & $\begin{array}{l}\text { Office Mixed Use } \\
\text { (OMU) }\end{array}$ & 70.4 \\
\hline
\end{tabular}

\begin{tabular}{|l|l|l|l|l|l|}
\hline 2030 & 0.30 & $\begin{array}{l}\text { Multi Family } \\
\text { Residential }\end{array}$ & 2.52 & $\begin{array}{l}\text { Village Mixed } \\
\text { Use }\end{array}$ & 2.35 \\
\hline Single Family Residential & 0.29 & & & $\begin{array}{l}\text { Fair Oaks } \\
\text { Mixed Use } \\
\text { (FOMU) }\end{array}$ & 3.77 \\
\hline $\begin{array}{l}\text { Residential Estate } \\
\text { Hillside }\end{array}$ & 0.73 & & & $\begin{array}{l}\text { Highway } \\
\text { mixed use }\end{array}$ & 3.06 \\
\hline Rural Residential & 1.19 & & $\begin{array}{l}\text { Gateway } \\
\text { mixed use }\end{array}$ & 3.77 \\
\hline $\begin{array}{l}\text { Single family } \\
\text { residential }\end{array}$ & 1.77 & & & & \\
\hline $\begin{array}{l}\text { Village residential } \\
\text { Planned } \\
\text { development }\end{array}$ & 1.40 & & & & \\
\hline
\end{tabular}

